\title{
Interferencias pragmáticas: aproximación ás estratexias de cortesía nas peticións en galego
}

\author{
Xemma Fernández López \\ Universidade de Vigo
}

\begin{abstract}
Resumo:
Neste artigo verificamos a pertinencia de falar de interferencias pragmáticas entre galego e castelán e a necesidade de estudar a pragmática do galego para poder dispoñer de datos útiles e necesarios para o ensino da lingua ou para a tradución.

$\mathrm{O}$ traballo céntrase no estudo dos xeitos de realizar un acto directivo que ameaza a imaxe pública de falante e oínte, como é a petición. Os datos, obtidos mediante técnicas de dramatización (xogos de rol), permiten a comparación das estratexias comunicativas postas en marcha por falantes de diferente idade, sexo e procedencia social.

Considerando unha escala que teña nun extremo linguas que optan por unha cortesía da deferencia e no outro linguas que prefiren unha cortesía da solidariedade, o galego, mesmo estando neste segundo grupo, estaría máis próxima da cortesía de deferencia que o castelán.
\end{abstract}

\section{Palabras chave:}

Lingua galega, interferencias pragmáticas, cortesía, peticións.

\begin{abstract}
:
This article looks at the importance of studying pragmatic interference between Galician and Spanish, and highlights the role of Galician pragmatics as a means of collecting useful and necessary data for the teaching or translation of Galician.

The article focuses on the different performances of directive speech acts (such as requests) which can threaten the public image of the speaker and the listener. Data which was collected through dramatization techniques, namely role plays, is used to compare the different communicative strategies used by speakers of different age groups, gender, social class and place of origin.

On a scale, which at one end positions languages that opt for deference politeness and at the other, languages that opt for solidarity politeness, Galician can be classified as the latter. Nevertheless, in comparison with Spanish, Galician can be considered closer to deference politeness.
\end{abstract}

Key words:

Galician language, pragmatic interference, politeness, requests. 


\section{Introdución}

Nos últimos anos, a investigación no eido da pragmática transcultural propiciou diversos estudos tanto comparativos como centrados en linguas concretas. Estes últimos, cunha perspectiva que se afasta dos intentos de universalidade iniciais, céntranse nos diferentes factores sociais que condicionan o que se pode e non se pode dicir en cada situación dentro dunha cultura determinada. Estes traballos describen as estratexias máis axeitadas e as formas e estruturas que son esperables e "normais" para transmitir determinadas forzas ilocutivas.

Hai estudos centrados nas interferencias pragmáticas ${ }^{1}$ no campo da didáctica de segundas linguas, pero estes son máis infrecuentes en situacións de contacto lingüístico. A idea básica que sustenta este traballo é que os idiomas galego e castelán utilizan distintas estratexias para "facer cousas con palabras". Os falantes das dúas linguas non usan o mesmo tipo de mecanismos conversacionais para acadar os seus fins, nin consideran igual de correctas e afortunadas determinadas actuacións lingüísticas para os mesmos casos.

Algúns tópicos sobre os galegos poderían ter a súa orixe nestas diferenzas pragmáticas xa que ao falar en castelán, os falantes tradicionais de galego empregarán estratexias e efectuarán escollas propias da súa lingua que poderán provocar interpretacións non pretendidas en oíntes casteláns. Por outra banda, na actualidade, frecuentemente escoitamos comentarios sobre a calidade lingüística dos neofalantes a cal podería ser tamén explicada como un déficit pragmático.

Tanto para a tradución como para o ensino de segundas linguas, este tipo de estudos son fundamentais. Hoxe ninguén pon en dúbida a necesidade dunha tradución que vaia máis alá da sintaxe e da semántica, do mesmo xeito que non podemos pensar na adquisición de linguas en termos de "competencia lingüística" sen considerar esta dentro dunha competencia comunicativa.

Con todo, a dimensión pragmática é frecuentemente descoidada tanto na tradución como no ensino do galego. Ao igual que a fonética, parece máis dificilmente "aprendible", mesmo se a didáctica de segundas linguas demostra desde hai anos que non é así. Tanto o ensino comunicativo da lingua como a tradución precisan deste tipo de estudos para se desenvolver dun xeito obxectivo e sistemático e non depender unicamente do "bo-facer" do docente ou do tradutor.

1 "Interferencia pragmática" pode resultar un termo un pouco estraño pero as primeiras caracterizacións globais fixéronse nos anos 70, ligadas a disciplinas como a Etnometodoloxía, a Etnografía da Comunicación ou a propia Pragmática. Sinala Gómez Capuz que: "El primer autor que plantea la posibilidad de préstamos que afecten al nivel pragmático es M. Clyne en sus trabajos sobre el habla de los immigrantes alemanes en Australia [...]. En un trabajo posterior, M. Clyne (1977) defiende explícitamente la existencia de interferencias ('transferences', en su propia terminología) en el nivel pragmático" (Gómez Capuz 1998: 136). 
En resumo, pretendemos subliñar a necesidade de levar a cabo un traballo de identificación de formas lingüísticas convencionalizadas e estratexias conversacionais (des)preferidas para diferentes situacións comunicativas propias do galego: que estruturas e estratexias prefire un falante galego para agradecer, protestar, queixarse, rifar, reclamar ou contar?

Se se esquece este aspecto e o ensino e a tradución seguen a priorizar os niveis léxico e morfosintáctico, a converxencia do galego cara ao castelán será dificilmente evitable. A este respecto, débese ter en consideración que as variedades máis formais e específicas do galego están a ser desenvolvidas a partir doutras linguas e convértense en modelos lingüísticos a través dos medios de comunicación e do ensino (véxase Kabatek 1991, 2004; Dobao 1999, 2004; Lorenzo Suárez 2004, entre outros).

\section{Estado da cuestión}

Os estudos de cortesía abordan o conxunto de estratexias conversacionais destinadas a mitigar conflitos, sobre todo nos casos nos que os obxectivos do falante non coinciden cos do destinatario. As regras de cortesía de Lakoff (1973) ou as máximas de Leech (1997) pretenden completar a explicación do significado-transmitido ofrecida polo principio de cooperación griceano e contribuír así á explicación dos actos de fala indirectos.

A proposta que durante anos dominou nos estudos sobre cortesía e da que son debedoras a práctica totalidade dos traballos dos últimos 20 anos, é a de Brown/ Levinson (1987). Estes autores aceptan como básico o principio de cooperación de Grice (1991) aínda que o concepto central da súa teoría é o de "imaxe pública" (face) desenvolvido por Goffman (1967), para quen cada persoa ten unha autoimaxe que pretende preservar en cada interacción social: o falante coida a súa imaxe e a do interlocutor por identificación emocional cos sentimentos do outro. Esta imaxe pública ten dúas caras, unha positiva (desexo de ser aceptado polos demais) e unha negativa (desexo de ter liberdade de acción). A partir de aquí, Brown e Levinson diferencian entre cortesía positiva (dirixida a preservar e reforzar a imaxe positiva do individuo) e cortesía negativa (centrada no coidado da imaxe negativa).

Para estes autores hai cinco estratexias posibles para a resolución de accións ameazadoras da imaxe pública, dependendo do risco que estas supoñan:

1. Se o risco é mínimo, a estratexia será aberta e directa: o falante amosa claramente as súas intencións e non considera necesario empregar ningunha estratexia de compensación (por exemplo: "faime un café"”).

2 Os exemplos están tirados dun cuestionario no que os enquisados debían escribir cinco formas diferentes de pedir un café ao chegar pola mañá á casa dun amigo ou dunha amiga sen almorzar. 
2. Aberta e indirecta con cortesía positiva: con compensacións orientadas a reforzar a imaxe pública positiva do intelocutor ("por que non tomamos un cafetiño?").

3. Aberta e indirecta con cortesía negativa: con compensacións orientadas a respectar a imaxe pública negativa do interlocutor, non se pretende limitar a liberdade de acción do destinatario ("Se houbese café feito, tomaba un", "Se non é abusar da túa confianza, tomaba un café").

4. Estratexia encuberta: o falante non mostra de forma explícita a súa intención; deste xeito evita que lle sexa atribuída a responsabilidade de ter realizado un acto ameazador. Así, ofrécelle ao destinatario diferentes interpretacións posibles ("Que ben ule ese café!" "Hoxe non tiven tempo de almorzar").

5. Non levar a cabo a acción.

A distinción entre cortesía positiva e negativa, consideradas universais por estes autores, foi criticada posteriormente, aínda que seguiu a estar na base de moitas reformulacións ${ }^{3}$. Así Blum-Kulka/ House/ Kasper (1989) falan de culturas que prefiren a cortesía da solidariedade e culturas con cortesía da deferencia. Kerbrat-Orecchioni (1992) fala de cortesía mitigadora (dirixida a evitar ou reparar as ameazas á imaxe) e cortesía valorizante (produción de actos corteses). Autoras como Bravo (1999) ou Marco (2005) chaman a atención sobre a non universalidade das relacións que cada cultura establece entre "eu" e "outro" e por tanto a relatividade de conceptos como "individuo" e "grupo" que se plasman no de "imaxe" de forma diferente segundo as necesidades de filiación e autonomía que se establezan na comunidade.

Outra das críticas feitas ao modelo de Brown e Levinson é que a cortesía non é avaliable dentro da mesma comunidade de forma descontextualizada. Por exemplo Escandell Vidal (1998) mantén unha visión da cortesía como parámetro totalmente dependente do contexto (no seu sentido máis amplo dentro dun enfoque cognitivo $)^{4}$. Tamén neste sentido, outros autores teñen analizado o concepto de cortesía e descortesía na interacción oral e a adecuación destas estratexias segundo o contexto. Por exemplo Briz $(2004,2007)$ diferencia entre "cortesía interpretada" e "cortesía codificada" xa que a cortesía ou descortesía dun acto de fala depende

3 Boa parte da investigación das últimas décadas tiña como obxectivo a interpretación, modificación ou refutación do modelo de Brown e Levinson.

4 Segundo esta autora, "la cortesía es un efecto que depende decisivamente de los supuestos previos que un individuo haya adquirido sobre cuál es el comportamiento socialmente adecuado; es, por tanto, un tipo particular de efecto contextual. Los enunciados que explotan algunas de las llamadas 'estrategias de cortesía' se procesan exactamente igual que cualquier otra clase de enunciado: combinando su contenido explícito con un subcojunto específico de supuestos adquiridos que incluyen supuestos sobre el comportamiento social esperable. El efecto cortés dependerá de la existencia de una norma cultural específica, relativa a la forma o al contenido del enunciado, y al grado de ajuste del enunciado con respecto a dicha norma (Escandell Vidal 1998: 15). 
da interpretación que deste fai o interlocutor nun determinado contexto, o mesmo que a "descortesía codificada" e a "descortesía interpretada". Por exemplo, un comportamento con cortesía codificada pode ser interpretado como moi descortés cando hai pouca distancia social entre os falantes.

A preocupación da pragmática pola cortesía foi en aumento nas últimas décadas tal como mostran os monográficos publicados no Journal of Pragmatics ou os estudos que se teñen desenvolvido sobre diferenzas pragmáticas e de cortesía en distintos lugares: inglés de Australia, francés do Canadá, alemán, hebreo, e arxentino (BlumKulka/ House/ Kasper 1989), hebreo e inglés americano (Blum-Kulka 1987), español peninsular e sueco (Bravo 1999), español e inglés (Cenoz/ Valencia 1996), polaco e inglés (Wierzbicka 1991) entre moitos outros. No eido hispánico este tipo de estudos está moi desenvolvido (véxase o monográfico de Oralia 2, 1999 e Diálogos hispánicos 22, 1998; Placencia/ Bravo 2002; Bravo/ Briz 2004; Bravo 2005; e Placencia/ García 2007 nos que se recollen traballos de diferentes linguas e enfoques).

Pola súa orixe, e como corrobora o noso traballo nalgúns puntos, o estudo da pragmática en galego debe ter moi en conta o desenvolvemento desta área na lingüística portuguesa. En Portugal destacan os traballos de Fonseca (1994) e teses doutorais como Casanova (1992) ou Fernandes Rodrigues (2002), no Brasil destacamos os estudos de Cirelli Apa (2005), Peres de Oliveira (2005) ou Lenertz Marcotulio/ Lima da Souza (2007).

No ámbito galego, a bibliografía sobre cortesía lingüística é aínda testemuñal. Simplemente queremos destacar, pola motivación que supuxeron para o noso traballo, a revisión da retranca dende a pragmática feita por Piccardi (2004), mesmo se non é tratada polo autor como estratexia de cortesía, e a análise dos marcadores conversacionais como marca de cortesía realizado por Moledo Leirado [Moreda Leirado] (2007) que, ao igual que Freixeiro Mato (2003) no campo máis xeral dos conectores oracionais, chama a atención sobre a presión do castelán nestes ámbitos.

Para este traballo escolléronse actos de fala directivos porque afectan de forma clara a imaxe social do falante. Para Leech (1997) son actos que entran en conflito coa cortesía, polo que esixen do falante a elección de estratexias que o mitiguen. Para Moreno Cabrera os actos de fala directivos caracterízanse por un punto ilocutivo no que:

el hablante quiere que el interlocutor haga algo. Por tanto, ahora la DA [dirección de ajuste] también va del mundo a las palabras: el hablante quiere que el mundo sea de un modo determinado respecto de lo que depende del interlocutor. Las CP [condiciones preparatorias] del acto ilocutivo directivo tienen que ver, entre otras cosas, con las posibilidades del interlocutor para llevar a cabo lo pedido: no se puede pedir a alguien algo que no puede hacer. Las CS [condiciones de sinceridad] tienen que ver con el deseo del que ordena de que se realice lo ordenado (Moreno Cabrera 1994: 358). 
Tomouse como base teórica para o traballo o "Proxecto transcultural de realización de actos de fala" (Cros-cultural Speech Act Realization Projet - CCSARP: Blum-Kulka/ House/ Kasper 1989), xa que gran parte del se centra nas peticións. Para unha análise máis exhaustiva, neste traballo e en Blum-Kulka (1987) as estratexias discursivas clasifícanse dependendo das partes das peticións nas que aparecen (apelativos, núcleo e reforzos) e non seguindo criterios frecuentes noutros traballos como o nivel gramatical ou pragmático ao que afectan (Haverkate 1994, Briz 2001).

Os apelativos son interxeccións que abren a intervención do falante e que, por un lado, chaman a atención do oínte, e por outro, poden adiantar o tipo de acto de fala que se vai realizar, xa que fai ostensión das súas intencións (poden manifestar fastío, sorpresa, desagrado etc.). O tipo de apelativo que se emprega (un alcume, un termo cariñoso ou familiar, a función social do oínte ou a relación de parentesco, entre outras) serven para resaltar a relación entre os interlocutores e adiantar as intencións do falante. En moitos casos tamén son o primeiro uso de cortesía codificada, que serve para predispoñer positivamente ao oínte.

O núcleo é a unidade mínima que pode realizar a petición, é dicir, é a proposición que explicita a vontade do falante. Pode estar orientada ao oínte ou ao falante. Para mitigar a forza podemos usar a primeira persoa de plural (sobre todo cando o falante ten máis poder) ou estruturas non persoais. Estratexia refírese á realización do acto de fala de forma máis ou menos directa. Na emisión do núcleo tamén se poden empregar modificadores da forza ilocutiva para intensificala ou atenuala. Úsanse como mitigadores sobre todo a modalidade oracional e os tempos verbais, mentres que os intensificadores máis comúns son a énfase prosódica, as repeticións ou os indicadores de peche (normalmente interxeccións que apuran o oínte para a realización do pedido). A forza ilocutiva tamén se pode ver acentuada ou mitigada por reforzos externos ao propio núcleo.

Para a análise pragmática é necesario contar con datos lingüísticos reais, porén está clara a dificultade de conseguir un corpus de fala espontánea para traballar sobre actos de fala tan concretos. Blum-Kulka/ House/ Kasper 1989, e outros traballos realizados en diferentes linguas e culturas baixo esta perspectiva (por exemplo, Cenoz/ Valencia 1996), empregan cuestionarios nos que o falante debe completar unha serie de diálogos. Outra variante deste tipo de enquisa é presentar ao falante unha serie de situacións comunicativas e pedirlle que escriba o que diría nelas (Dumitresco 2004). Pero con este tipo de técnica de recollida non se obteñen trazos suprasegmentais e os enquisados non teñen en conta a posibilidade de negociación da petición en varias quendas como sinalan Beebe/ Cummings (1996) ao analizar as carencias deste tipo de cuestionarios. Alén disto, este formato permite ao informante reflexionar sobre a súa resposta e ser menos espontáneo. No caso do galego, unha maior elaboración pode supoñer un achegamento consciente a modelos de lingua que o falante considerase máis "correctos" ou axustados ao estándar, feito que se pretende evitar no posible por razóns xa expostas na introdución. Por todo isto, 
finalmente os datos obtivéronse mediante a gravación de intervencións en xogos de rol (Cohen 1996, Márquez Reiter/ Placencia 2005), xa que isto permitía controlar o contexto de situación e que os falantes respondesen de forma aberta.

\section{Metodoloxía}

O enfoque do traballo é cualitativo xa que era necesario identificar fórmulas e estratexias reais empregadas polos falantes galegos nas peticións. Sería dar paus de cego iniciar unha investigación cuantitativa sen este tipo de datos que fagan posible a elaboración de cuestionarios axeitados. Os obxectivos concretos a que se dirixiu o estudo foron:

1. Localizar as estruturas lingüísticas preferidas polos falantes galegos para levar a cabo unha petición.

2. Comprobar se o galego ten fórmulas para as peticións convencionais indirectas diferentes do castelán.

3. Analizar o tipo de estratexias conversacionais e o tipo de cortesía máis empregados en galego para pedir algo dependendo do status social de falante e oínte, o grao de familiaridade entre eles e a dificultade e factibilidade do pedido.

4. Comprobar se a escolla de estruturas e estratexias varía segundo a idade, o xénero e a procedencia xeográfica dos falantes, e se esta variación se pode relacionar cun proceso de converxencia cara ao castelán.

Para o deseño das variables que poderían afectar as formas de pedir, tivéronse en conta os factores que, segundo Brown/ Levinson (1987), determinan o nivel de risco potencial para a imaxe do falante: poder relativo do falante sobre o oínte $(\mathrm{P})$, distancia social que separa aos interlocutores (D) e grao de imposición que cada acto de fala supón dentro dunha lingua determinada $(\mathrm{G})^{5}$; concretadas nas variantes "poder", "familiaridade" e "relevancia da petición", respectivamente.

Canto ao poder, distancia vertical entre interlocutores, diferéncianse tres situacións: cando o falante ten máis poder (A), cando o oínte ten máis poder (B) e cando non existen diferenzas de poder marcadas socialmente entre falante e oínte, anteriores á interacción (C). Tivéronse en conta, ao lado de relacións de poder "efectivo" (xefe-empregado), situacións nas que a relación de poder, aínda sendo máis ben "afectivo", parece igualmente relevante (por exemplo pai/nai-fillo/filla ou sogra/ sogro-nora/xenro ou mesmo irmá(n) maior/irmá(n) pequeno/a).

5 Para Brown/ Levinson (1987) estes factores son categorías relevantes para o cálculo do risco de calquera intercambio lingüístico en calquera cultura e permiten ao falante elixir o nivel de cortesía requirido. Concretan esta teoría sobre as Accións que Ameazan a Imaxe Pública (AAIP) na fórmula: $\operatorname{Risco}(\mathrm{AAIP}) \mathrm{x}=(\mathrm{D}+\mathrm{P}+\mathrm{G}) \mathrm{x}$ 
Do mesmo xeito, en moitos casos a interpretación da forza ilocutiva depende directamente da relación de poder entre falante e oínte. Así, en moitas ocasións nas que o falante ostenta o poder, este podería levar a cabo unha orde e non unha petición. De non facelo, e optar por mitigar unha imposición contextualmente lexitimada, pon de manifesto a súa preocupación por coidar a súa propia imaxe social e a do oínte. Que un acto de fala directivo se realice como orde, petición, suxestión, etc. vai depender sobre todo desta variable. No traballo preferiuse non facer unha clasificación dos actos de fala directivos ${ }^{6}$ e optouse por analizar todo como peticións. Se ben é certo que, cando o falante ten maior poder, hai familiaridade e a petición é pouco relevante, en ocasións o acto de fala está máis próximo da orde que da petición. Pola contra, cando o oínte ten maior poder e hai pouca familiaridade, nos casos presentados nas entrevistas (pedir ao xefe un ou varios días libres) os falantes en moitos casos o que piden ao xefe é permiso, que o poder lexitime a súa actuación para que esta non teña consecuencias indesexables.

Familiaridade refírese á distancia horizontal entre os interlocutores. Este é un parámetro escalar que depende de moitos aspectos non controlables como a frecuencia dos encontros entre os interlocutores, o tempo que hai que se coñecen, as vivencias comúns ou mesmo como foi o día no que se realizou a entrevista (xa que se recollen situacións nas que os informantes debían imaxinar interaccións con algún membro da familia, o xefe, algún empregado etc.). Para o estudo só se considerou presenza ou ausencia de familiaridade, aínda que se tentou buscar contextos nos que estes extremos foran ben perceptibles.

Por último, interpretouse o grao de imposición de Brown/ Levinson (1987) en dous sentidos: como de esperable era o pedido nun determinado contexto (canto máis esperable menos ameazante resultará para o interlocutor) e como de difícil resultaría para o oínte levala a cabo (canto maior costo para o oínte máis estratexias deberá poñer en xogo o falante para conseguir o seu obxectivo e coidar a imaxe negativa do interlocutor). Así, o inesperado dunha petición nun contexto determinado e o costo e grao de imposición para o falante serán directamente proporcionais á relevancia da petición.

A combinación destes tres parámetros ten como resultado doce contextos que esixirían do falante diferentes graos de cortesía e estratexias lingüísticas. Peticións non relevantes (1) e relevantes (2), entre interlocutores que teñen familiaridade entre eles $(\mathrm{F}+)$ ou non $(\mathrm{F}-)$ en casos nos que o falante ten máis poder $(\mathrm{A})$, nos que o oínte ten máis poder $(\mathrm{B})$ ou nos que non teñen roles predeterminados respecto do poder (C). Así, un exemplo marcado como A1 (F-) supón que ao falante se lle propuxo unha situación na que el tiña maior poder, non había familiaridade e a relevancia da petición era baixa, mentres $\mathrm{C} 2(\mathrm{~F}+)$, marcará un contexto na que non hai diferenza

6 Para a análise e clasificación de actos de fala directivos pódese consultar Moreno Cabrera (1994) ou Mulder (1998). 
de poder preestablecida entre os interlocutores, hai familiaridade entre eles e a relevancia da petición é alta.

Debido á dificultade de localizar nun corpus de galego oral peticións concretas que puidesen cubrir todas estas variantes, buscouse un método de produción de datos artificial no que se puidese controlar o contexto e o tipo de acto de fala requirido ao falante, como xa se sinalou.

Realizáronse entrevistas a trinta informantes que foron escollidos tendo en conta as variantes de idade, sexo e procedencia xeográfica (rural ou urbana). Diferenciamos tres grupos de idade: menor de 25 , entre 25 e 50 e maior de 50 . Buscouse que os falantes de medio rural fosen representativos de falantes tradicionais con pouco contacto co castelán, mentres que os falantes urbanos desenvólvense en contextos nos que o contacto de linguas é constante.

Para isto procurouse que os e as informantes de cada un dos grupos cumpriran certo perfil: os informantes rurais son homes e mulleres que viven en núcleos de poboación menores a 200 habitantes e que teñen ou tiñan como principal medio de vida a gandería tradicional, mesmo se algúns dos máis novos traballan en núcleos de poboación maiores (ata 2.000 habitantes) e noutros sectores. Incluímos neste grupo catro informantes que na actualidade viven en vilas e traballan no sector terciario pero que seguen moi ligados a poboacións coas características descritas. Para todos eles o galego é practicamente a única lingua das súas relacións sociais e do núcleo familiar (no que normalmente conviven tres xeracións). Os informantes deste grupo non teñen estudos ou só cursaron o ensino obrigatorio polo que tampouco o contacto co castelán foi prolongado neste ámbito. Pola contra os e as informantes de procedencia urbana viven en poboacións que superan os 100.000 habitantes. Practicamente todos teñen estudos universitarios e desenvolven (ou desenvolveron) profesións que se axustan á súa formación. Aínda que o galego é a lingua maioritaria das súas relacións sociais e familiares non é a única e tampouco é a lingua inicial da totalidade.

Para diferenciar os falantes na transcrición e no uso de exemplos, usamos unha combinación de letras e números que sexan transparentes ás características sociais do ou da informante. A primeira letra será R (rural) ou U (urbano/a) segundo a procedencia, a seguinte será $\mathrm{N}$ para os falantes novos ( $<25$ anos), M para os maiores de 50 e nada para o grupo de idade intermedia. A última letra será M (muller) ou $\mathrm{H}$ (home). O número diferencia os distintos informantes dentro de cada grupo. Así RMM2 será a segunda muller entrevistada, maior de cincuenta anos e de procedencia rural, e UH4 será o cuarto home urbano con idade entre 25 e 50 anos.

Procurouse que as situacións fosen o máis familiares posibles para os e as falantes polo que se deseñaron enquisas diferentes para o medio rural e o urbano, para falantes menores de 25 anos e para os outros dous grupos de idade e para homes e mulleres do rural, xa que consideramos que as tarefas neste medio están moi diferenciadas. 
Durante a elaboración do traballo tamén se recolleron datos de fala espontánea en establecementos comerciais e conversas familiares, ademais da realización dalgúns cuestionarios escritos, que non se inclúen de forma sistemática na análise, pero das que si se tiran algúns exemplos que confirman o recollido nas entrevistas.

\section{Análise dos datos}

Para a análise das peticións adaptáronse as categorías establecidas por Escandell Vidal (2004), seguindo o modelo de Blum-Kulka (1987) e Blum-Kulka/ House/ Kasper (1989), recollidas na seguinte táboa:

\begin{tabular}{|c|c|c|c|}
\hline \multicolumn{4}{|c|}{ Apelativos } \\
\hline \multicolumn{4}{|c|}{$\begin{array}{l}\text { Relación co falante }(\mathrm{R}) \\
\text { Apelido ou nome }(\mathrm{N}) \\
\text { Alcume }(\mathrm{AL}) \\
\text { Termo cariñoso }(\mathrm{F}) \\
\text { Elemento para chamar a atención (A) } \\
\text { Atención + cortesía }(\mathrm{C}) \\
\text { Interxección (sorpresa, molestia etc.) (I) }\end{array}$} \\
\hline \multicolumn{4}{|c|}{ Núcleo } \\
\hline Perspectiva & Estratexia & \multicolumn{2}{|c|}{ Modificadores: (internos) } \\
\hline \multirow{2}{*}{$\begin{array}{l}\text { Cara ao oínte }(\mathrm{O}) \\
\text { Cara ao falante }(\mathrm{F}) \\
1^{\mathrm{a}} \text { persoa de plural } \\
(\mathrm{N}) \\
\text { Impersoal }(\mathrm{NP})\end{array}$} & \multirow{2}{*}{$\begin{array}{l}\text { Modalidade } \\
\text { imperativa (I) } \\
\text { Realizativo } \\
\text { explícito (R) } \\
\text { Realizativo } \\
\text { modificado (Rm) } \\
\text { Obriga (OB) } \\
\text { Desexo (D) } \\
\text { Necesidade (N) } \\
\text { Suxestión (S) } \\
\text { Condición } \\
\text { preparatoria (CP) } \\
\text { Indirecta (IN) }\end{array}$} & Mitigadores & Intensificadores \\
\hline & & $\begin{array}{l}\text { Interrogativo (IT) } \\
\text { Oración condicional } \\
\text { (OC) } \\
\text { Aspecto (A) } \\
\text { Imperfecto (IM) } \\
\text { Condicional (CN) } \\
\text { Futuro (F) } \\
\text { Marcas de cortesía } \\
\text { (MC) } \\
\text { Atenuantes (AT) }\end{array}$ & $\begin{array}{l}\text { Repeticións }(\mathrm{RP}) \\
\text { Énfase prosódico } \\
(\mathrm{E}) \\
\text { Indicadores de } \\
\text { peche }(\mathrm{P})\end{array}$ \\
\hline \multicolumn{4}{|c|}{ Reforzos } \\
\hline \multicolumn{2}{|c|}{ Mitigadores } & \multicolumn{2}{|c|}{ Intensificadores } \\
\hline \multicolumn{2}{|c|}{$\begin{array}{l}\text { Preparatorios (PR) } \\
\text { Procura de compromiso previo (CP) } \\
\text { Xustificación (X) } \\
\text { Promesa de compensación (C) } \\
\text { Marcas de cortesía (MC) } \\
\text { Minimizadores da imposición (AT) }\end{array}$} & \multicolumn{2}{|l|}{$\begin{array}{l}\text { Ameaza (A) } \\
\text { Reproche (R) } \\
\text { Insulto (I) }\end{array}$} \\
\hline
\end{tabular}

Táboa 1 
Nos exemplos os apelativos aparecen en cursiva, o núcleo en letra negra e os reforzos en letra normal. Cando é relevante para a análise o tipo e distribución dos reforzos, estes inician e finalizan coa abreviatura que para cada un se marca na táboa 1, entre parénteses. Así, o exemplo 5:

UMH1 Oyee fulanito!/ (X)Aquí hai MOITO CHOLLOO $\rightarrow(\mathrm{X})$ temos que deixar o chollo acabado// hasta quee $\rightarrow / /$ que non podemos deixalo así para mañán $\uparrow(\mathrm{R})$ así que hai que espabilar(R)// (P)veña!(P) (A1 F-) ${ }^{7}$

ábrese cun apelativo, seguido dun reforzo mitigador que busca a xustificación (X) e do núcleo duplicado que é intensificado por medio dun reproche $(\mathrm{R})$ e un indicador de peche $(\mathrm{P})$.

\subsection{Apelativos}

Nas peticións recollidas o uso de apelativos non é moi amplo, mais de todos os xeitos é necesario ter en conta que están ligados á espontaneidade, polo que a mostra pode non ser moi representativa. A súa función é preparar o oínte para a petición e predispoñelo positivamente cara ao falante e as súas necesidades cunha finalidade moi similar aos mitigadores que buscan o compromiso previo e a xustificación.

Así, o máis frecuente é o uso de interxeccións que demostran sorpresa ou incomodidade (ou as dúas cousas ao mesmo tempo) que serve como primeiro sinal ostensivo de que o falante ten un problema. É o primeiro apelo á solidariedade do oínte e, en moitos casos, o falante agarda a resposta do interlocutor antes de formular o núcleo da petición. Así podemos interpretar a primeira intervención de $\mathrm{UH} 2$ en 1:

1. UH2: merda!

E: que che pasou? Home

UH2: deixei a carteira na casa $\downarrow$ // impórtache se me pagas o café? e despois amañamos $\rightarrow / /$ págocho despois $\rightarrow(\mathrm{C} 1 \mathrm{~F}+)$

Nas peticións que involucran oíntes sen relación de poder co falante e descoñecidos para estes o apelativo serve, en moitos casos, de primeira oportunidade para mostrar cortesía negativa convencionalizada. O falante comeza pedindo desculpas por invadir o espazo do oínte (Desculpe señora, señora por favor, por favor señora, mire perdone etc.).

7 Os símbolos empregados para a transcrición dos exemplos están tirados de Briz/ grupo Val.Es.Co (2002) (pódense consultar no anexo I). 
Non é o lugar para tratar polo miúdo todos os marcadores conversacionais recollidos no corpus. O lector poderá atopar unha análise deste tipo no traballo de Moledo Leirado [Moreda Leirado] (2007).

\subsection{Núcleo}

O núcleo da petición é o enunciado que fai explícito o contido proposicional desta. En case todas as peticións analizadas o falante esfórzase en mitigar a forza ilocutiva da petición mediante diferentes recursos dirixidos na súa maioría á locución, pero tamén á ilocución (por exemplo a elección de orientación). Nalgunhas das emisións a atenuación vai moito máis aló e non teñen un núcleo claro; son peticións totalmente indirectas nas que se empregan outras estratexias para a transmisión da forza ilocutiva.

Corroborando o que sinala Blum-Kulka (1987) para as linguas románicas, a maioría das peticións están orientadas cara ao oínte. Porén no corpus tamén son abundantes as peticións orientadas cara ao falante. En moitos casos o falante no canto de formular a súa petición, limítase a expoñer o seu desexo ou necesidade ao oínte,

2. UM3: oye $\uparrow$ mira $\uparrow$ quería que me fixeras hoxe esto $\downarrow$ (A1 F-)

Porén, é nos casos nos que o oínte ten o poder nos que máis se recorre a este tipo de orientación. Nestas situacións (unha empregada pide o día ao xefe para asuntos propios ou o fillo pide aos pais para saír) o falante emprega esta estratexia e agarda que a resposta sexa a cortés (a preferida) nestes contextos: a lexitimización do seu comportamento por parte do poder:

3. UMM1: Necesito que me dEIxe o dÍa $\uparrow$ teño o fillo umaal $\uparrow$ pasei unha noite moi mala estou moi preocupada e necesito que me deixe un día para poder acompañalo ao médico $\rightarrow(\mathrm{B} 1 \mathrm{~F}-)$

Esta estratexia ten moi en conta que no galego unha prohibición, como agresión aberta á imaxe negativa do oínte, ten un gran custo para a imaxe positiva do falante e este tratará de evitala, como explica $\mathrm{RNH} 2$ ao preguntarlle pola súa petición:

4. RNH2: Teño que mir $\downarrow / /$ xa quedara cuns amigos $\downarrow$ teño que mir $\uparrow$ hoxe non che podo axudar $\downarrow$ (B1 F+)

E: Pero non lle pides en ningún momento que che deixe iir? niin $\rightarrow$

RNH2:

\&porque se llo digo iguaal $\uparrow$ non- /// me dice que no $\uparrow$ e así $\uparrow$ se lle digo que xa quedei xa

E:

RNH2:
$\&$ pois $\mathrm{xaa} \rightarrow \&$

pois xa non se lle fai mal $\rightarrow$ 
O uso da primeira persoa do plural é habitual, segundo Briz (2001), cando o falante ten máis poder como mostra de cortesía positiva. Este, xunto co recurso á impersonalidade, son as estratexias menos usadas. Nos casos nos que aparecen, o falante busca non asumir totalmente a responsabilidade da petición:

5. UMH1 Oyee fulanito!/ Aquí hai MOITO CHOLLOO $\rightarrow$ temos que deixar o chollo acabado// hasta quee $\rightarrow / /$ que non podemos deixalo así para mañán $\uparrow$ así que hai que espabilar// veña! (A1 F-)

6. UMH2 Imos ver $\downarrow /$ hai un chollo que hai que sacar adiante como sexa $\rightarrow$ eh?// ee non hai tempo xa $\rightarrow$ así que non hai [mmm] [3"] xa posibilidade de disculpas $\downarrow$ por favor teñen que quedar CINco persoas HOxe ata rematar o traBAllo a ver $\uparrow / /$ quen queda? (A1 F-)

A escolla de estratexias na realización do núcleo é moi diferente segundo o nivel de ameaza que a situación supoña para os interlocutores, mais tamén segundo o falante sexa rural ou urbano. Por exemplo, fóra de situacións que implican pouco risco para a imaxe (maior poder do falante, maior familiaridade e menor relevancia da petición) a maioría dos usos do imperativo pertencen a falantes de procedencia rural. O uso deste aspecto é maioritario en situacións nas que hai familiaridade, como tamén indica Moledo Leirado [Moreda Leirado]:

Outro exemplo ilustrativo da asimilacións de patróns de cortesía é a diminución no uso do imperativo, moi presente na nosa lingua fronte a outras como o español ou o inglés. Se pensamos nunha conversa mantida durante unha reunión de amigos, alguén pode dicir "pásame o sal" sen que ninguén resulte ameazado, pois o ton en que se enuncia fainos inferir que non se trata dunha orde, senón dunha petición. Moledo Leirado [Moreda Leirado](2007: 197)

Porén, nas situacións de menos familiaridade e nas que o falante non ten o poder, a forza do imperativo é contrarrestada con diferentes atenuantes, como marcas de cortesía codificada (MC) (7), promesa de compensación (C) (8) ou xustificación da pertinencia da petición $(\mathrm{X})(7,8$ e 9$)$ :

7. RMM2: (MC)Por favor $\uparrow(\mathrm{MC})$ dígame que hora é $\uparrow(\mathrm{X})$ que non teño hora $\rightarrow(\mathrm{X})(\mathrm{C} 1 \mathrm{~F}-)$

8. RMM1 mira (MC) por favor $\uparrow(\mathrm{MC})(\mathrm{X})$ fáltanme tres euros $\rightarrow(\mathrm{X})$ déixeme subir $\uparrow(\mathrm{C})$ cando chegue aa $\rightarrow$ a onde teño que ir $\mathrm{xaa} \rightarrow$ ou cando volva de volta $\uparrow$ porcurarei devolverche eses tres euros $\downarrow$ (C) (C2 F-)

9. RMH1: Acórdate que aí hai unhos baches $\rightarrow(\mathrm{X})$ que son en zona pública $\uparrow(\mathrm{X})$ dille que $\rightarrow$ que debe debe cubrilos $\uparrow(\mathrm{B} 1 \mathrm{~F}-$ ) 
Con todo o uso que fan as mulleres (7 e 8) e o que fai o home (9) son moi diferentes. As mulleres conseguen por medio de atenuantes (xustificación, promesa de compensación, entoación...) e marcas de cortesía que a emisión se aproxime a un rogo convencionalizado. O caso de RMH1 é diferente, está a pedirlle ao pedáneo da aldea que se arranxen problemas no camiño, e considera que é o seu dereito pedilo e a obriga da autoridade solucionalo: a xustificación da petición aberta e directa é que estes problemas son en zona pública, por tanto que é obriga da autoridade preocuparse deles. Alén disto na segunda parte da emisión demostra que é consciente dos "poderes" do pedáneo e non lle esixe máis alá das súas funcións: transmitir as necesidades do pobo ao concello que é o que realmente ten a capacidade de actuar (dille que debe cubrilos). Neste caso a ideoloxía explica a escolla. O resto de falantes que responderon a esta situación empregan outras estratexias (un realizativo modificado -quería pedirlle-, unha suxestión - a ver se fai o favor e se acorda- ou unha obriga impersonalizada -hai que acordarse-).

Noutros contextos, os falantes recorren na práctica totalidade dos casos a estratexias de petición indirectas, xa que o uso de peticións directas por medio de verbos realizativos (teño que pedirlle, teño que pedirche, quería pedirlle) é moi pouco habitual (6 casos). Esta estratexia aparece, sobre todo, en contextos nos que o falante ten maior poder, pero a pouca familiaridade ou a relevancia da petición xa non permite o uso do imperativo. O máis empregado nestes casos, sobre todo cando o falante ten maior poder, é o recurso á obrigatoriedade.

Antes de seguir tratando estratexias que aumentan en indirectividade, débese ter en conta que, como sinala Blum-Kulka (1996b), existen dous tipos de peticións indirectas: as indirectas convencionais (normalmente baseadas en precondicións e formuladas como preguntas: "Tes café feito?", ás que poderiamos engadir as baseadas nas condicións de sinceridade, "Apetecíame un café") e pedidos indirectos non convencionais ("Hoxe non me deu tempo a almorzar"). No segundo caso é máis difícil explicar a interpretación que o oínte fai da forza ilocutiva directiva por medio de implicaturas conversacionais.

Blum-Kulka (1987) considera a expresión do desexo como outra das estratexias indirectas posibles para o núcleo da petición, xa que se explicita o contido proposicional da petición. Esta autora non considera como tal a expresión da necesidade. Pero en peticións como:

10. UH3: mira! A miña moza está bastante enferma $\uparrow$ / e gustaríame quedar $\rightarrow$ (B1 F-)

11. UM3: Carmen teño que quedarme na casa con Alberto $\downarrow$ que está malo e non podo ir a traballar $\downarrow$ (B1 F-)

12. RNH2: Oye/ mira $\uparrow$ necesito o día libre que // surgiu un imprevisto na casa $\uparrow$ e non podo ir hoxe $\downarrow$ (B1 F-) 
a diferenza é a intensidade coa que o falante se implica no que necesita, debe ou quere facer e que o aparta das súas responsabilidades laborais, polo tanto trátase de recursos para a intensificación ou a atenuación do discurso por selección léxica (seguindo a Briz 2001). UM3 (11) podería dicir, con efecto parecido, que "necesita quedarse con Alberto" igual que RNH2 (12) podería "querer o día libre" ou podería "gustarlle ter o día libre" porque hai un imprevisto na casa. Todas elas son xustificacións para unha petición que non se fai de forma aberta e directa que é o día libre ou permiso para faltar ao traballo sen que isto teña consecuencias negativas.

Segundo Sperber/ Wilson (1986: 301), o desexo do falante porque un estado de cousas se faga efectivo é a condición de sinceridade dos actos de fala directivos. Mostrar, facer ostensión do "estado de cousas desexables" como necesidade e non como simple desexo é unha intensificación desta condición que exime o falante de responsabilidade. Desexo e necesidade teñen a perspectiva do falante mentres que o imperativo (orde) e a obriga están orientadas cara ao oínte. Pódese ver nestas catro estratexias certo paralelismo: imperativo e desexo mostran de forma aberta a vontade do falante, mentres obriga e necesidade mitigan a responsabilidade do emisor sobre o pedido que xa non depende da súa vontade, senón das circunstancias:

\begin{tabular}{|l|c|c|}
\hline & $\begin{array}{c}\text { + vontade do falante } \\
\text { > responsabilidade }\end{array}$ & $\begin{array}{c}\text {-vontade do falante } \\
\text { < responsabilidade }\end{array}$ \\
\hline Orientado ao oínte & Orde (modo imperativo) & Obriga \\
\hline Orientado ao falante & Desexo & Necesidade \\
\hline
\end{tabular}

Táboa 2

$\mathrm{Na}$ suxestión, pola contra, o falante asume a responsabilidade dunha petición orientada cara ao oínte pero mostrando a súa vontade de non imposición. É por tanto unha estratexia que demostra un alto grao de cortesía de deferencia ou cortesía negativa, o falante non quere invadir o espazo do oínte e, aínda que asume a súa petición, "cede" ao oínte todo o poder para que este a teña en conta ou non.

Esta fórmula, como outras peticións baseadas en condicións preparatorias, protexen de risco a imaxe negativa e positiva do oínte porque lle dan opcións de rexeitar o pedido, sen que isto sexa atribuíble á súa pouca vontade de colaborar, senón que se deberá á súa falta de posibilidades para facelo. Mais, tamén por iso, lle deixa ao oínte toda responsabilidade de coidar ou non a súa propia imaxe positiva que se verá afectada en caso dunha resposta despreferida (é dicir, de non colaboración). Cede, por tanto, poder pero tamén responsabilidade.

Na maioría dos casos a suxestión en galego lévase a cabo por medio dunha estrutura condicional, na que a realización do condicionante depende totalmente da vontade 
ou posibilidades do oínte, é dicir, que se basea nas condicións preparatorias para a petición. Con todo, non sempre nestas fórmulas se apela á posibilidade de que o falante "poida" facer o que pedimos, moitas veces claramente depende da súa vontade:

13. RNH1: Se me pode atender hoxe $\uparrow / \mathrm{e} \rightarrow \mathrm{e}$ que teño traballo $\uparrow$ e non podo pedir outro día $\rightarrow$

14. RMH2: Se fai o favor $\uparrow$ e me dice $\rightarrow$ que hora é?

aínda que en moitos casos tamén se combina con reforzos preparatorios (PR), busca de compromiso previo (CP), xustificacións $(\mathrm{X})$ ou promesas de compensación (C):

15. MH1 Oes compañeiro mira! (PR)Vouche facer unha cabronada $\downarrow$ (PR) eh? $(\mathrm{X})$ Pero non me queda máis remedio $\rightarrow$ como sabes andamos con moito cholloo $\uparrow / /$ a empresa vai ben $\uparrow$ temos que facer unha entrega aí de material e eres absolutamente imprescindible $\rightarrow(\mathrm{X})(\mathrm{C})$ euu // xa verei como che compenso este tempo $\uparrow$ en tempo $\uparrow$ ou en cartos $\uparrow$ como queiras (C) /// (X) pero temos que facer o traballo (X) $e h$ ? (CP) Síntoo moito $\uparrow(\mathrm{CP}) / /$ i fala coa muller a ver se podedes amañar ee/ deixamos as vacacións para outro momento $\downarrow$ (B2 F-)

16. $\mathbf{R N H 2 : ~}$ mira $\uparrow(\mathrm{X})$ fanme falta cincuenta euros $\downarrow$ porque quedoume a carteira na casa $\uparrow(\mathrm{X})$ se mos podes deixar hoxe // (C)e cando nos volvamos ver $\uparrow$ devólvochos $\downarrow$ (C) $(\mathrm{C} 2 \mathrm{~F}+)$

17. RH2: bos dias $\uparrow$ se me pode atender $\uparrow(\mathrm{X})$ que non puiden pedir vez $\uparrow(\mathrm{X})$ (B2 F-)

Con frecuencia aparece mitigada a forza da petición polo uso do imperfecto de indicativo ou de subxuntivo (este último case sempre coa terminación do pluscuamperfecto):

18. RMH2: Se puideras e me fixeras o favor $\uparrow$ a ver se me podías levar a Lugo $\uparrow(\mathrm{A} 2 \mathrm{~F}+)$

19. RM3: [á súa sogra] Se me quedara mañá usted todo o día na casa $\uparrow$ $(\mathrm{X})$ eu iba $p a$ Monterroso $\rightarrow$ porquee $\rightarrow$ como está bon día $\uparrow$ pos $\uparrow$ podía traballar $\rightarrow(\mathrm{X})(\mathrm{B} 2 \mathrm{~F}+)$

20. RMM2: Ana por favor $\uparrow$ se me deras unhas nabizas $\rightarrow(X)$ que eu non as teño $\uparrow(\mathrm{X})$

Esta fórmula aparece moitas veces introducida por "a ver" como mitigador de forza: 
21. UMM1 (PR)Va-i-a chasco que acabo de levar $\uparrow / /$ quería convidarvos e non teño con que $\downarrow$ puf que bolón! (PR)// A ver si me deixades cartos ou me pagades vós o café hoxe $\downarrow(\mathrm{C} 1 \mathrm{~F}+)$

22. RMM1:porfavor $(\mathrm{X})$ necesito a vosa axuda $\uparrow(\mathrm{X})$ a ver se vos levantades $\rightarrow$ (C) aínda que despois durmais a si- aa $\rightarrow$ a siesta $\rightarrow(C)(A 2 ~ F+)$

Este recurso é moi frecuente tamén en portugués do Brasil. Peres de Oliveira (2005: 126) xustifícao así:

Primeiramente, a hipoteticidade veiculada à condicional possibilita ao falante expressar a oração núcleo como uma alternativa, daí a afirmação de Ford (1997) de que a noção de alternatividade/opcionalidade associada à hipoteticidade da condicional atenua um ato considerado impositivo. Ou seja, o falante enuncia a oração núcleo como uma opção, e não como um fato dado, que poderia ser mais impositivo para o ouvinte.

Em segundo lugar, a situação hipotética criada pela oração condicional promove um certo distanciamento entre o falante e seu enunciado. Ao se distanciar de seu enunciado, o falante coloca o ouvinte como o centro desse mundo mental, procurando assim atenuar os efeitos que o ato veiculado pela oração núcleo poderia causar, preservando, então, a face do ouvinte.

Esta é, con diferenza, a fórmula máis empregada por falantes rurais e o grupo de maior idade urbano, é dicir, parece a forma de petición con maior grao de convencionalización entre falantes tradicionais, xunto coas interrogativas baseadas nas condicións preparatorias (exemplos 22-25). Estas preguntas sobre a capacidade do oínte para levar a cabo a acción requirida é unha das fórmulas máis frecuentes para as peticións convencionalizadas en linguas europeas. Esta fórmula gaña terreo fronte á suxestión nos falantes urbanos e máis novos (sobre todo en circunstancias que requiren maior cortesía).

23. UH1: Podería demorar na entrega do traballo? (B1 F-)

24. UM1: Rapaces $\rightarrow$ / non teño un duro $\downarrow / /$ podedes deixarme pelas? para $\rightarrow$ para $\rightarrow$ para pagar $\downarrow(\mathrm{C} 1 \mathrm{~F}+)$

25. RNM1: Tes hora? (C1 F-)

26. RNM1: Cámbiasnolo para outro día? [falando dun exame cun profesor] (B1 F-)

Atópanse tamén gran cantidade de peticións indirectas non convecionalizadas, o que supón deixar abertas múltiples opcións de interpretación para o oínte co que non ten por que verse comprometida a imaxe pública de ningún dos interlocutores. 
É frecuente neste tipo de estratexia empregar actos de fala expresivos (apelativos e outros marcadores conversacionais) cos que o falante pon de manifesto os seus sentimentos cara á realidade ou cara a un estado de cousas desexable. Tampouco son estrañas as emisións que se corresponden con actos de fala asertivos ou expresivos ${ }^{8}$ sen que exista realmente un núcleo que realice o acto directivo:

27. RNH2: $O i$ ! quedoume a carteira na casa $\rightarrow(\mathrm{C} 1 \mathrm{~F}+)$

28. RM3: ostraa $\rightarrow / /$ quedoume a carteira na casa $\rightarrow / / /$ teño QUIR a por $\mathrm{ELA} \rightarrow(\mathrm{C} 1 \mathrm{~F}+)$

Pero estas peticións indirectas (en contra do postulado polos primeiros estudos sobre cortesía) non supoñen necesariamente maior delicadeza nin dar máis opcións ao oínte, sobre todo se é o falante o que ten maior poder na interacción. Segundo UMM2 (traballadora dun restaurante) 29 é como a súa xefa pediría que os empregados quedasen máis tempo para limpar o peixe que acaba de chegar. Estes saben perfectamente o que se lles está dicindo e as consecuencias que terá unha interpretación incorrecta da emisión:

29. UMM2: Acaba de chegar este pescado. (B1 F-)

O corpus tratado non dá mostras reais da frecuencia de uso de estratexias indirectas deste tipo, moito máis usuais na fala espontánea. Por exemplo o emisor moitas veces emprega varias quendas dunha conversa para facer a petición:

30. UH2: joder // sabes que me pasou o outro día?

E: que che pasou logo?

UH2: pois que tiven un golpe co coche $\uparrow / /$ e agora teño que pagar a reparación $\rightarrow$ e a verdá /// que non sei como vou facer $\uparrow / /$ porque ando moi mal de pelas $\rightarrow / / /$ tou un pouco así cos cartos $\rightarrow$ [3"] non // non me van chegar [4"]

E: $x a$

UH2: e bueno $\rightarrow$ [5"]

E: necesitas moitas pelas?

UH2: son $200 € \downarrow$ home eu se os puidera $\uparrow$ non chos pediría $\rightarrow$ porquee $\rightarrow$ pero bueno $\rightarrow / /$ neste caso $\rightarrow$ ee $\rightarrow$ necesitoos $\downarrow$ e hasta dentro de un mes non vou cobrar $\uparrow$ ee $\rightarrow$ / se puideras deixarmos e despois $\rightarrow$ pois $\uparrow$ adiantábachos outro momento $\rightarrow$ xa chos vou pagando pouco a pouco $\rightarrow$

8 Respecto desta clase de "cruzamentos" entre intención do falante e tipo de acto de fala, Hernández Sacristán (1995) propón considerar as diferentes categorías de actos de fala baixo o punto de vista da teoría de prototipos, tendo en conta que dentro dunha mesma categoría hai representantes prototípicos e outros periféricos. Alén disto, demostra que non son estraños os casos de intersección e neutralización categorial entre os diferentes tipos de actos de fala. En galego os actos de fala directivos e expresivos parecen "complementarse" en moitas ocasións e en diferentes direccións (o reproche, o desexo, a necesidade etc.). 
E: bueno, vale

UH2: non che importa? Fasme ese favor?

E: si, si neste mes non estou mui agobiada $\rightarrow$ podoche facer $\rightarrow$ / pódochos deixar $\rightarrow$ non te preocupes $\downarrow$

UH2: home $\rightarrow$ graciñas $\rightarrow$ agradécese $\downarrow$ a verdade é que amigos así $\uparrow$ pois non hai moitos $\downarrow$ pero $\uparrow$ seguro que que non tes problemas? Que mos podes deixar? (C2 F+)

Neste caso o falante expón o seu problema e intenta provocar o ofrecemento do falante antes de ter que facer a petición. Vemos como as pausas se incrementan ata parar a conversa e obrigar ao interlocutor a intervir. UH2 interpreta "necesitas moitas pelas?" como un ofrecemento cando realmente non tería por que ser así, e non só iso se non que contesta dicindo que se puidera non llos pediría, pero realmente, cando llos pediu e cando accedeu o seu interlocutor a prestarllos?

Neste e noutros exemplos $(15,16,20$ ou 21$)$ o falante parece ter a esperanza de que o oínte acceda ou mesmo se ofreza a realizar o insinuado, antes de ter que chegar a explicitar a petición. Colocar os reforzos antes do núcleo pode ter esta estratexia na súa orixe.

O uso de estratexias indirectas non convencionalizadas, contra a opinión de Brown/ Levinson (1987), prefírese en situacións nas que hai certo grao de familiaridade entre oínte e falante porque necesitan un contexto común para se "desambiguar" e que o oínte poida inferir o sentido da emisión. O oínte necesita saber que se lle está pedindo algo, e necesita saber o que; polo tanto o falante sabe que debe deixar as pistas suficientes para que o oínte chegue a esta conclusión. Desde este punto temos que considerar a escala de indirección de Leech (1997: 200), xa que o custo que lle supón ao oínte averiguar a intención do falante non sempre é rendible. Se somos demasiado creativos, corremos o risco de que o noso interlocutor non nos entenda, como nesta interacción espontánea recollida nun comercio, na que un falante (rural de máis de 50 anos: $\mathrm{RMH}$ ) lle pide á vendedora (urbana do grupo intermedio de idade: UM) que lle cambie dez euros. A pesar de que ten familiaridade con ela e de que se trata dunha situación máis ou menos frecuente, a vendedora non comprende as intencións do seu interlocutor nun primeiro momento:

31. RMH: DOUche dez euros $\uparrow / /$ e voume $\downarrow$

UM: dez euros?

RMH: si

UM: ah! Serán do outro día?

RMH: No // no

UM: \& e logo? Por que?

RMH: Non queres calderilla?

UM: Ah! Si si

RMH: arma a mau $\rightarrow$ 
Aínda dentro das estratexias posibles para a formulación do núcleo o falante conta con outro tipo de recursos, os modificadores que poden graduar a súa forza ilocutiva. No caso das peticións non é moi frecuente o uso de intensificadores da forza ilocutiva.

No tocante aos mitigadores, un dos recursos máis empregados é o modo e o tempo verbal da cláusula que funciona como núcleo. O uso de interrogativas e oracións condicionais como mitigadores xa foi advertido ao falar de condicións preparatorias e suxestións (exemplos 13-25). Canto á escolla do tempo verbal, o uso do presente de indicativo é a fórmula menos cortés, fronte ao imperfecto de indicativo e ao condicional. Nas estruturas condicionais aparece aínda unha posibilidade máis formal, o imperfecto de subxuntivo.

O imperfecto ten unha ocorrencia moito menor que o condicional, pero a distribución da escolla é significativa. Dos seis usos do imperfecto de indicativo, catro son de falantes de procedencia rural, e os outros dous de falantes urbanos maiores:

\section{RNH3: quería ir de festa $\uparrow(\mathrm{B} 1 \mathrm{~F}+)$}

33. RM2 por favor// se me podía atender $\uparrow$ porque me encontro mui mal $\rightarrow$ mui mal // e non podo esperar hasta mañá $\rightarrow(B 2$ F- $)$

Mentres, o condicional conta con 16 ocorrencias, a maioría en estruturas interrogativas centradas nas condicións previas ${ }^{9}$ :

34. UNM1: pois $\rightarrow$ mira $\uparrow$ quee $\rightarrow / / /$ poiss-see / é que teño que pagar $\rightarrow / /$ un plazo / do ordenador // ee $\rightarrow \mathrm{e} / /$ pois nada $\rightarrow / / /$ me viñeron moitos gastos $\uparrow((?))$ see $\rightarrow[3$ " $]$ poderías deixarme $\uparrow$ / $50 €$ que me fan falta para pagalo? $(\mathrm{C} 2 \mathrm{~F}+)$

35. UMH3 Señoral por favor $\uparrow$ non lle importaría $\rightarrow$ solo teño esto $\downarrow /$ i é un minuto $\downarrow /$ non lle importaría deixarme pasar? (C1 F-)

En castelán a petición convencionalizada indirecta máis frecuente é deste tipo (Haverkate 1994, Blum-Kulka 1996b) fronte a outras linguas como o portugués nas que é maioritario o uso do imperfecto de cortesía (ILTEC 2005).

Porén, entre os falantes de procedencia rural non aparece nunca este tempo como recurso mitigador, o que nos leva a pensar que non é un recurso propio do galego senón unha interferencia das peticións convencionalizadas do castelán. Estes falantes prefiren as estruturas condicionais e no caso de empregar interrogativas o tempo preferido é o presente (e o imperfecto nuns poucos casos).

9 Para unha análise do funcionamento do condicional de cortesía pódese consultar Haverkate (1994). 
O futuro tamén é usado para marcar maior cortesía codificada que o imperfecto de indicativo $^{10}$ :

36. RMH: Poderasme enseñar unhas mudas?

37. RMM: Poderame dicir en canto sale a chaqueta que teñen aí no escaparate?

O uso do futuro ten dous efectos parellos, un ligado ás condicións necesarias da petición e outro ás preparatorias. A acción requirida do oínte está, obrigatoriamente, orientada cara ao futuro; ademais, ao ser o tempo usado para expresar a dúbida no presente, ten maior forza para a mitigación xa que introduce, ao mesmo tempo, a dúbida do falante sobre as condicións preparatorias.

Con todo, nas peticións recollidas mediante o cuestionario non se atopan usos deste recurso. Aínda que talvez se poida interpretar así o uso da perífrase IR + infinitivo, nalgúns casos, ligado ao sentido de obriga:

38. UM2: hui! vais ter que invitarme $\rightarrow$ / que vin $\rightarrow$ sen cartos $\downarrow(\mathrm{C} 1 \mathrm{~F}+)$

39. RNM2: $\mathrm{OH}$ ! olvidei a carteira $\uparrow / /$ que vergonza /// vadesme ter que invitar $(\mathrm{C} 1 \mathrm{~F}+)$

ou HABER + infinitivo recollida nunha conversa espontánea:

40. RMM: se che axuda Adrián, haslle dar a volta a ese colchón que eu non podo. (A1 F+)

A referencia á segunda persoa por medio da segunda ou a terceira persoa de cortesía pode tamén ser empregado como mitigación da forza ilocutiva do núcleo. As situacións preferidas para usar esta forma de cortesía son as de menor familiaridade dos interlocutores. Con todo, os falantes do rural emprégana tamén sempre que o oínte ten máis poder e a relación non implica demasiada familiaridade (médico, pedáneo, xefe...) e algúns falantes para dirixirse a membros da familia de máis idade:

41. RM3: [á sogra] quédeme aquí un momentiño / que teño que ir comprar á tienda $\rightarrow /$ e veño ahora $\rightarrow(\mathrm{B} 1 \mathrm{~F}+)$

Os falantes urbanos prefiren usar outro tipo de atenuantes no núcleo, sobre todo a entoación:

10 Os exemplos 36 e 37 pertencen a conversas espontáneas recollidas nunha tenda de roupa dunha vila duns 2.000 habitantes. En ambos os dous casos os informantes son maiores e de poboacións rurais circundantes. 
42. UH4: mira esta temporada [4"] estou dedicándome a istoo// mínimo dez horas/// así quee/ como non parece que vaiaa $\rightarrow$ que vaia a ir a menos pois eu creo que era momento dee $\rightarrow /$ de pensar en quee// se suba aquí ${ }^{\mathbf{o}}(\mathbf{o o} \rightarrow \mathbf{s o l d o} \text { eh? })^{\mathbf{o}} / /$ eu de boa gana pediría máis vacacións $\uparrow / /$ pero como sei que iso non vai poder ser $\uparrow$ pois///pois creo que é o momento $\downarrow /$ porque esto non hai quen o aguante $\downarrow$ (B2 F-)

marcadores conversacionais (sobre todo subliñadores da alteridade que parecen buscar a aprobación do oínte e metadiscursivos que demostran a incomodidade de ter que facer a petición):

\section{UNH1 Sabelal anda $\uparrow$ vaime pola chaqueta $\uparrow(\mathrm{A} 1 \mathrm{~F}+)$}

44. UM3 oye quee $\rightarrow$ / mee cambiaron o-oo plan de viaxe // que iba facer $\uparrow$ e necesitoo $\rightarrow / /$ que-que bueno $\uparrow(())$ que veñas para facer as vacacións antes $\downarrow$ (B2 F-)

Os intensificadores, dirixidos a aumentar a forza ilocutiva da petición, resultaron bastante raros nos datos recollidos, probablemente porque en ningunha das situacións se engadiron pautas sobre o estado de ánimo do falante. Aínda así os falantes urbanos empregan estes recursos nalgunhas situacións.

Atopamos indicadores de peche nalgunhas das peticións realizadas en contextos cun alto grao de familiaridade:

45. UM2: Adrián $\uparrow$ deixa a naranxa que non é para xogar $\uparrow(\mathrm{A} 1 \mathrm{~F}+)$

Adrián: e?!

UM2: que deixes a naranxa cariño $\uparrow / /$ que non é para xogar $\rightarrow / /$ oíchesme? [4"] eh? [ademais neste caso o falante necesita intensificar unha petición que fallou na súa primeira emisión]

46. UMH2: Iago $\uparrow /$ vaime pola chaqueta que teño un pouquiño de presa $\rightarrow$ $\underline{\text { veña } \uparrow \text { corre } \uparrow}(\mathrm{A} 1 \mathrm{~F}+)$

A énfase prosódica e a repetición tamén son bastante empregadas, sobre todo nas situación nas que hai maior familiaridade (véxase tamén o exemplo 34):

47. UH2: pero os teus amigos podes velos cando queiras $\downarrow$ CAMbia $\downarrow / /$ fala con eles $\downarrow / /$ cambia $\rightarrow$ que mañán marchamos de viaxe $\rightarrow(\mathrm{A} 2 \mathrm{~F}+)$

Este tipo de intensificación aparece tamén a miúdo nas peticións de permiso para resaltar a necesidade da actuación do falante (3). 


\subsection{Reforzos}

A maioría das veces o núcleo non aparece só, senón no medio dunha auténtica argumentación que busca mover ao oínte á acción e xustificar a petición. BlumKulka/ House/ Kasper (1989) clasifican estes reforzos segundo estean destinados a aumentar a forza ilocutiva ou a mitigala.

O número de reforzos que se consideran na petición é xa un dato significativo. Canto máis dificultade entrañe a petición para o falante, isto é, canto máis risco supoña para a súa imaxe pública o acto de fala, máis reforzos emprega. Así, nas situacións nas que hai familiaridade entre os interlocutores e a petición non é moi relevante o núcleo aparece só en bastantes ocasións ou acompañado dun apelativo ou dunha xustificación. O mesmo ocorre cando a petición é pouco relevante e non hai familiaridade (na cola do supermercado), xa que son situacións máis convencionalizadas (como preguntar a hora a alguén na rúa, comprar nunha tenda ou facer trámites burocráticos) nas que por respecto á imaxe pública negativa do interlocutor (e á súa propia) inténtase que o intercambio sexa o máis rápido posible:

\section{RNH1: Vaime buscar unha chave $\uparrow(\mathrm{A} 1 \mathrm{~F}+)$}

49. RNM1: Déixame pasar que só é un quilo de azúcar? (C1 F-)

Polo contrario, as situacións nas que a relevancia da petición é alta e ademais non hai familiaridade, os reforzos multiplícanse: o falante busca primeiro o compromiso do oínte (CP) e logo xustifica $(\mathrm{X})$ a petición, ademais de prometer algún tipo de compensación (C) en moitos casos (véxase tamén exemplos como 15, 16 ou 41):

50. UMM1 (CP)MIra $\uparrow$ canto o sinto $\uparrow$ eu sei que ti tes dereito a estas vacaciós $\uparrow$ $(\mathrm{CP}) / /$ eu pídoche por favor quee $\rightarrow$ sigas poor $\rightarrow$ unhos días máis $(\mathrm{C})$ despois xaa $\uparrow$ verEI como podo favorecerche $\uparrow(\mathrm{C})$ peroo // (X) hai moito chollo e tes que quedar a traballar $\rightarrow(\mathrm{X})(\mathrm{B} 2 \mathrm{~F}-)$

Como xa se sinalou ao falar da intensificación da forza no núcleo, esta estratexia non é moi empregada nas emisións recollidas. Aparece en situacións nas que o falante ten máis poder, xa que o contexto lexitima unha maior forza. Son emisións con moi pouca cortesía codificada, incluso nalgúns se pode falar de descortesía codificada (Briz 2004, Watts 2003). A (des)cortesía, interpretada nestas situacións cun grao de familiaridade tan alto, é moi diferente (e ás veces mesmo oposto) á (des)cortesía codificada.

O reproche $(\mathrm{R})$ é bastante empregado polos falantes, que no papel de pais e nais, se dirixen aos fillos/as. Pode servir de xustificación da petición, no caso de menor forza:

51. RMM2: Veña levántate $\uparrow(\mathrm{R})$ que É tempo $\uparrow(\mathrm{R})(\mathrm{A} 1 \mathrm{~F}+)$ 
Ese "que É tempo" pódese interpretar como unha xustificación de por que o oínte se debe levantar pero tamén como un reproche de que xa leva demasiado tempo durmindo.

O reproche serve nalgunhas das peticións para "convencer" o oínte da necesidade de actuar dunha determinada maneira. En termos de cortesía podemos consideralo un ataque aberto á imaxe negativa (non facer o que prefire) e positiva (non actuar conforme ao esperado polo interlocutor ou o grupo), pero, en xeral, non terá grandes consecuencias na relación dos interlocutores debido a que socialmente está lexitimado este comportamento no contexto. Nos exemplos que seguen os pais e a nai optan por reprochar aos fillos unha conduta que aínda non levaron a cabo, no canto de pedirlles que queden:

52. UMH2 Iago $\rightarrow$ home! // podías quedar AQUÍ $\downarrow$ (X) imos reunirnos todos ee tiña gana desta festa $\uparrow / /$ i é o meu cumpreanos $\uparrow(\mathrm{X})(\mathrm{R})$ sempre ten que haber un mona na $\mathrm{cASA} \uparrow /$ intentando algún negocio $\rightarrow(\mathrm{R})$ pero bueno $(\mathrm{R})$ si queres facer $\rightarrow$ fai o que queiras $\uparrow / /$ o que che pete $\rightarrow(R)(A 2 \mathrm{~F}+)$

53. UMH1 Vamos a ver Antón $\uparrow(\mathrm{R})$ quee $\rightarrow$ coño $\uparrow(\mathrm{X})$ pa un día que temos de festa que nos podemos xuntar todoss $\uparrow(\mathrm{X})$ ben podes renunciar ti a salir cos amighos eh? // Quee $\uparrow$ por unha ves no ano non pasa nada $\uparrow$ (R) (A2 $\mathrm{F}+)$

54. UMM1 (R) PEro vós sempre estades no mismo $\uparrow /$ estades enredando sempre con tanta ocupación $\uparrow(\mathrm{X})$ un fin de semana que sabedes que tedes que estar na casa porque a vosa mai quere que estedes $\uparrow(\mathrm{X})$ sempre estades con estes incordios $\downarrow$ (R) (A2 F+)

Como é esperable unha emisión deste tipo atópase tamén intensificada a nivel discursivo por medio da selección léxica (enredar, incordios), modificación morfosintáctica ( a un día, tanta ocupación, estes incordios...), uso de hipérboles ( $p$ a unha ves no ano), diferentes marcadores discursivos (vamos a ver, que coño, eh? ou o pero que inicia a emisión de UMM1 xa como oposición ao contexto), e mesmo o insulto (mona).

A situación do núcleo na intervención é o primeiro aspecto a ter en conta para a mitigación da forza ilocutiva. Nos casos nos que o falante pretende xustificar máis o feito de estar a facer unha petición ou quere reducir a imposición desta, normalmente adianta os reforzos, así, cando chega ao núcleo, situado nos últimos lugares, o seu interlocutor xa sabe o que se lle vai pedir, xa que terá posto en funcionamento mecanismos de inferencia similares aos das peticións indirectas (exemplos 15, 16, 20, 34 ou 47). É un recurso cun funcionamento similar á elipse da conclusión, que Briz (2001) sinala como mitigador da imposición. O falante parece contar ademais cun oínte disposto a coidar a propia imaxe positiva, que moitas veces atallará o acto de petición para amosarse disposto a colaborar ou ofrecer a súa axuda (como espera o falante do exemplo 30). 
A xustificación (X) é o reforzo máis empregado xunto cos minimizadores da imposición (M). No corpus hai moi poucas peticións non xustificadas (só en situacións nas que a relevancia da petición é moi baixa e a familiaridade moi alta). Canto máis relevante sexa a petición e maior a distancia social entre os falantes (tanto vertical como horizontal) máis posibilidades temos de atopar diante do núcleo algunha xustificación da petición:

55. RNH1: (X) Está miña mai mala $\uparrow(\mathrm{X})(\mathrm{M})$ si pode ser $\uparrow(\mathrm{M})$ pode deixarme o día libre? (B1 F-)

56. RMM2: (MC) Por favor (MC) (X) non puiden pedir vez $\rightarrow$ non había vez $\mathrm{xa} \rightarrow \mathrm{e}$ agora tiven que vir a Lugo por arreglar unha cousa $\uparrow$ e poiss $\rightarrow$ viñen igual $\rightarrow(\mathrm{X})$ a ver se fai $\mathrm{o}$ favor de atenderme $\uparrow(\mathrm{B} 2 \mathrm{~F}-)$

Ou antes e despois do núcleo:

57. UH3: desculpe $\uparrow(\mathrm{PR})$ este é o seu coche? (PR) (X) Porque teño que saír $\rightarrow$ (X) se o pode mover un momento $\uparrow / /(\mathrm{X})$ e para que poida saír e xa está $\downarrow$ (X) $(\mathrm{C} 1 \mathrm{~F}-)$

58. UMH1 Miraa/ fulano $\uparrow(\mathrm{X})$ teñoo /// o coche no taller $\rightarrow$ danmo hoxe pola tarde e a verdade é que tiven moitos gastos este mes e a verdade é que estou sen sen chica $\downarrow$ (X) // así que si me podes deixar douscentos euros $(\mathrm{X})$ paa $\rightarrow$ pa paghar o arreghlo porque coaa $\rightarrow$ co do taller non teño confianza pa pedirlle que me deixe levar o coche así $\uparrow(\mathrm{X}) /(\mathrm{C})$ cobro o día trinta $\mathrm{f} \rightarrow$ faltan tres días e xa chos devolvo $\uparrow$ e non creo que haia problema (C) $(\mathrm{C} 2 \mathrm{~F}+)$

Xunto coa xustificación o falante busca habitualmente deixar claro dende o primeiro momento a incomodidade e a dificultade que lle supón a petición. Moitos argumentos preparatorios buscan diminuír a responsabilidade do falante (véxase tamén o exemplo 15):

59. UMM1: Mira (PR) é unha situación delicada $\uparrow / /$ fáiseme moi costa arriba $\rightarrow(\mathrm{PR})$ teño que pedirche $\operatorname{cartos} \uparrow(\mathrm{X})$ teño $\mathrm{uu} \rightarrow$ un mes fa-TAL gastei todo $\downarrow /$ quédanme tres días para $\operatorname{cobrar} \uparrow(\mathrm{X}) /$ pídoche que me adiantes douscentos euros $(\mathrm{X})$ porquee $\rightarrow$ teño que pagar algunha avería no coche $\uparrow \mathrm{ii} \rightarrow / /$ estou afogada $\rightarrow(\mathrm{X})(\mathrm{C} 2 \mathrm{~F}+)$

O falante non só se preocupa da súa imaxe: dar opcións para que a resposta despreferida non afecte a imaxe do oínte é un recurso moi frecuente de cortesía positiva, por iso se busca minimizar a imposición e dar outras opcións ao oínte. As mulleres buscan en todos os casos analizados ser menos impositivas que os homes: 
60. UM4: Mira Marta! (PR) eu xa sei quee $\uparrow / /$ bueno que tiñamos previsto remataar $\uparrow /$ pois hoxe as sete $\uparrow / /$ vale? que pasa? (PR) (X) Ca-xurdiu un imprevisto que eu non contabaa $\uparrow(\mathrm{X}) / / \mathrm{i}$ entón $(\mathrm{M})$ non $\mathrm{sei} \rightarrow$ como o ves? (M) ves factiblee// que nos quedemos hastaa // que rematemos? (X) porque é algo que ten que estar mañán $\uparrow$ bueno $\downarrow$ pois ten que estar mañán $\rightarrow(\mathrm{X})(\mathrm{M})$ non sei $\uparrow$ como o ves? $(\mathrm{M})(\mathrm{A} 1 \mathrm{~F}-)$

61. $\mathbf{R M 3}$ bueno // $(\mathrm{X})$ non teño vez $\uparrow$ pero é quee $\rightarrow$ eu teño un problema $\rightarrow(\mathrm{X})$ se me pode contestar $\uparrow / /(\mathrm{M})$ é solamente un minuto $\downarrow(\mathrm{M})$ e $(\mathrm{M})$ se non $\uparrow /$ pois veño outro día $\rightarrow(\mathrm{M})(\mathrm{B} 2 \mathrm{~F}-)$

62. RNM2: señora // por favor $\uparrow / /$ pódeme deixar pasar (X) que levo solo esto $\uparrow$ é que teño moita prisa $\rightarrow(\mathrm{X}) / /(\mathrm{M})$ se non é motia molestia $\uparrow / /$ se non $\uparrow$ non pasa nada // e? Dá igual $\rightarrow /$ se non $\uparrow$ espero $\downarrow(\mathrm{M})(\mathrm{C} 1 \mathrm{~F}-)$

Cando a relevancia da petición é alta é moi frecuente que o falante reforce a súa petición con algún tipo de promesa de compensación (C) para o oínte:

63. UMH2 Benito! (PR) sinto DARche unha mala noticia $\uparrow(\mathrm{PR})$ ee $\rightarrow / /(\mathrm{X})$ hai unha punta de traballo e ti sabes XA perfectamente que é un traballo que $\mathrm{m} \rightarrow$ que non podemos aprazar de ningunha maneira $\uparrow(\mathrm{X})$ así que $\uparrow$ non che queda máis remedio que que que seguires no traballo $\downarrow / /(\mathrm{C})$ agora tamén che quero dicir unha cousa $\uparrow /$ o próximo ano $\rightarrow$ a final de ano fa-LAmos e vamos revisar o soldo $\rightarrow(\mathrm{C})$ pero $\mathrm{e} / \mathrm{e} \rightarrow(\mathrm{X})$ ti sabes que can-do HAI un traballo urXENte non se pode dicir que non $\downarrow$ (X) (B2 F-)

A busca de compromiso previo (CP) é menos recorrente que os reforzos anteriores e parece restrinxida a contextos de familiaridade alta e gran relevancia da petición (neste caso a informante interpreta todo o intercambio):

64. UM2: (CP) Necesito un favor! (CP) e dirían $\uparrow$ que? e eu diría $\uparrow$ que me prestes cartos $\rightarrow(\mathrm{X})$ porque tiven aí uun $\rightarrow$ un accidente $\rightarrow(\mathrm{X})$ e dirían $\uparrow$ canto? pois aíi $\rightarrow$ uns douscentos euros $\downarrow(\mathrm{C} 2 \mathrm{~F}+)$

xa que, en situacións máis convencionalizadas nas que o que se busca é a rapidez e a efectividade do intercambio, usar reforzos de compromiso previo pode inducir a erros de interpretación ou verse como un exceso de cortesía con efectos negativos. Resultaría cando menos estraña unha pregunta así na cola dun supermercado:

65. UH2: e mire $\rightarrow$ perdoe $\rightarrow / /(\mathrm{CP})$ podo podo preguntarlle unha cousa? (CP) $\mathbf{E}:$ si $\downarrow$ que pasou?

UH2: mira $\rightarrow$ é que necesitaría $\uparrow$ pois $\rightarrow / /$ pagar $\rightarrow(\mathrm{X})$ só teño este cartón $\rightarrow$ e teño o coche aí $\rightarrow /$ mal aparcado $\rightarrow(X) / / /$ impórtalle se paso por diante?] ( $\mathrm{C} 1 \mathrm{~F}-)$ 
Sobre todo se o falante espera a que a outra persoa responda, esta pode interpretar que vai iniciar un intercambio moito máis longo e que a petición será relevante e custosa para a súa imaxe social, co que pode provocar no oínte certa incomodidade e mesmo rexeitamento.

Outros informantes usaron este tipo de reforzo, pero executado de maneira diferente, por exemplo como suxestión, ou mesmo como pregunta pero sen esperar a resposta:

66. UH4: Disculpe mire $\uparrow /(\mathrm{CP})$ a ver se me pode facer un favor $\uparrow(\mathrm{CP}) / /(\mathrm{X})$ que teño o coche aíi $\rightarrow(\mathrm{X})(\mathrm{X})$ solo levo unha barra de pan acabo xaa// rápido (X) (C1 F-) (C1 F-)

67. UM4: mira por favor eee $\rightarrow(\mathrm{CP})$ podo preguntarlle unha cuestión? (CP)// si mira $\rightarrow(\mathrm{X})$ é que acabo de saír do traballo $\uparrow$ a verdade é que me chamaron porque a miñ $\rightarrow$ un familiar meu acaba de ingresar $\uparrow(X) / /(X)$ fáltanme cincuenta céntimos de euro para coller o billete $(\mathrm{X})$ // non lle importaría eee// darmos? eee sería/// vaia me faría un favor enorme $\rightarrow(\mathrm{C} 2 \mathrm{~F}-)$

Fronte a este recursos máis argumentativos existen outros dirixidos exclusivamente a expresar cortesía codificada (MC):

68. UMM1: (MC)Pídolle por favor(MC) que me dEIXE $\uparrow(\mathrm{X})$ teño o cocheestá por aí a policía municipal $\uparrow /$ teño o coche en segunda fila $\uparrow /(\mathrm{X})(\mathrm{MC})$ por favor $(\mathrm{MC})(\mathrm{X})$ solo teño este cartón de leite $\uparrow(\mathrm{X})$ déixeme por favor que pague primeiro eu $(\mathrm{X})$ para poodeermee $\rightarrow$ evitar a multa $\rightarrow(\mathrm{X})(\mathrm{C} 1 \mathrm{~F}-)$

As ocorrencias deste reforzo concéntranse nas peticións nas que a distancia social horizontal entre os interlocutores é maior e, ao contrario do resto de reforzos, é usado sobre todo por falantes procedentes do ámbito rural, que parecen preferir o uso de cortesía codificada.

Os falantes poñen en funcionamento outros moitos recursos discursivos para a modificación tanto interna como externa da forza ilocutiva. Por exemplo o uso de diminutivos (teño un pouquiño de presa: 46, é solo un momentiño: 41) e cuantificadores (hai unha punta de traballo: 63, só é un quilo de azúcar: 49, solo teño este cartón: 68 etc.) que buscan mostrar o menor custo da acción para o falante e a maior necesidade da acción para o oínte. Algúns casos de selección léxica funcionan, sobre todo en falantes urbanos, como marcas de grupo, para subliñar a cortesía de solidariedade e para restar formalidade e posiblemente cortesía codificada á emisión (non teño un duro: 73 ou estou sen chica: 58), do mesmo xeito aparecen dialectalismos $(53,58)$ que se evitan en situacións máis formais.

Tamén son moi empregados os recursos suprasegmentais (como mostra 42 e 60), sobre todo unha curva entonativa predominantemente ascendente como índice 
de cortesía (Haverkate 1994) e a suspensión no fin da intervención na procura da resposta do oínte. Igualmente hai abundantes pausas e reformulacións nos momentos máis difíciles da petición co que, consciente ou inconscientemente o falante apela á empatía do oínte e demostra que lle resulta incómodo invadir o espazo deste e mesmo pode evitarlle a realización do núcleo se o oínte se adianta ás súas necesidades. Baixar a voz (60) é un recurso mitigador moi efectivo ao igual que a énfase na pronuncia ( 52 ou 68) ou o soletreado (59) dalgunha palabra o son para realzar partes do discurso, normalmente nas que se expón a importancia ou a necesidade do pedido.

Son moi frecuentes tamén diferentes tipos de elementos supraoracionais, sobre todo operadores discursivos de formulación e marcadores conversacionais, como xa se sinalou. Dentro deste último grupo teñen gran ocorrencia os subliñadores de alteridade que contribúen á mitigación da imposición e buscan a resposta do outro (relacionada coa mitigación dialóxica exposta por Briz 2001) e os metadiscursivos que, como as reformulacións e os silencios, marcan a incomodidade ou a necesidade que o falante ten de buscar a mellor forma de formular a petición para o éxito.

Son empregados múltiples recursos deste tipo que quedan á marxe das dimensións deste traballo. Baste dicir que, se o uso de reforzos é menos común entre falantes de procedencia rural, estes empregan máis recursos discursivos. Analizaremos só dous casos que nos chamaron especialmente a atención: o uso do verbo "acordar" e dos fóricos "aquí" e "aí".

69. RMM1: ai! (PR)que ben que o encontro aquí $\uparrow(\mathrm{PR})$ porquee $\rightarrow$ quería pedirlle $\uparrow(\mathrm{M})$ que candoo $\rightarrow$ seña oportuno $\uparrow$ oou candoo $\rightarrow$ poida $(\mathrm{M})$ que se acorde deste camiño $\uparrow(\mathrm{X})$ que estáa $\rightarrow$ intransitable $\downarrow$ (X) (B1 F-)

70. RMH1: Acórdate que aí hai unhos baches $\rightarrow(\mathrm{X})$ que son en zona pública $\uparrow(\mathrm{X})$ dille que $\rightarrow$ que debe debe cubrilos $\uparrow(\mathrm{B} 1 \mathrm{~F}-)$

71. RMH2: A ver se fai o favor e se acorda deses baches $\uparrow$ que hai // $\mathbf{n} \rightarrow \mathbf{n o}$ camiño $\downarrow$ (B1 F-)

72. RH2: Hai que acordarse dos BAches $\rightarrow$ que hai por AÍ $\uparrow(B 1 \mathrm{~F}-$ )

É destacable (aínda que non se poida considerar relevante pola escaseza de datos recollidos) que nas peticións dirixidas ao pedáneo para arranxar o camiño todos empreguen o verbo "acordarse" para mitigar a petición (independentemente de que as súas estratexias sexan máis ou menos directas). Pode ser unha forma de dar poder ao oínte xa que, como en moitos casos, o resultado depende da súa vontade, aquí en concreto, da súa memoria. A coincidencia na elección semántica (todos os preguntados), parece indicar que é un recurso minimamente convencionalizado, polo menos na zona de Lugo onde se realizaron as enquisas. 
Os fóricos "aquí" e "aí" en situacións de confianza parecen funcionar como mitigadores da forza impositiva e reforzo da relación entre falante e oínte (como o uso dunha lingua menos formal, de xiria ou de dialectalismos que viamos en falantes urbanos). Perde a súa referencia espacial no contexto para gañar unha referencia afectiva de "espazo" común:

73. RNH3: Págame aí // (X)que non teño un duro $\rightarrow(\mathrm{X})(\mathrm{C} 1 \mathrm{~F}+)$

74. RNH2: trae paquí a chavee $\rightarrow$ [risas] $(\mathrm{A} 1 \mathrm{~F}+)$

Tamén pode funcionar como modificador para mitigar a relevancia do pedido:

75. RNH2: (X)tiven un golpe $\rightarrow(\mathrm{X})$ fanme falta aí douscentos euros $\rightarrow(\mathrm{X})$ que non me chegan para este mes $\downarrow$ (X) $(\mathrm{C} 2 \mathrm{~F}+)$

\section{Discusión}

A necesidade de maior ou menor cortesía en función das tres variantes consideradas nas situacións comunicativas (poder, familiaridade e relevancia da petición), non ofrecen moitas diferenzas respecto dos datos obtidos para outras linguas. En cambio, as estratexias preferidas en cada caso si amosan maior especificidade, aínda que varíe dependendo das características do informante.

Canto ao parámetro "poder", parece que a distancia social vertical ten menos relevancia que a horizontal. Canto maior sexa esta distancia máis se mitigará a forza ilocutiva da petición. En principio, os falantes de procedencia rural amosan maior deferencia co poder. Aínda que debemos facer algunhas aclaracións respecto dos informantes e as situacións presentadas nas entrevistas que poden ter influído sobre este resultado. O falante urbano mostra sempre unha maior familiaridade co xefe que o falante de procedencia rural, e este feito parece mitigar a distancia vertical. Isto está claramente condicionado, por un lado, pola ideoloxía pero, por outro lado, tamén polo nivel de formación (básica no caso dos informantes rurais e superior no caso de practicamente todos os do medio urbano) e o tipo de traballo que isto implica. Os falantes rurais que traballan no medio rural non teñen relacións sen familiaridade nas que eles teñan máis poder, xa que normalmente non teñen traballadores que dependan deles. Tampouco teñen xefe, polo que as relacións de poder que se establecen son, na súa maioría, por "formación" ou oligarquía (o médico, o veterinario, técnicos, o pedáneo, o alcalde etc.) o que pode explicar que estes falantes reaccionen calculando un maior risco nestes intercambios e polo tanto, empregando un grao maior de cortesía. 
En contextos onde o falante ten máis ou igual poder que o seu interlocutor, é frecuente que este mitigue a súa petición cando sería posible non facelo, ou mesmo que ceda o poder ao oínte. Estas estratexias están directamente ligadas coa preservación da imaxe positiva do falante porque como sinala Álvarez Muro (2005: 23) "ceder en control da prestigio y esto se logra a través de ciertas estrategias manipuladoras que reconocen al interlocutor su imagen y su territorio". Os falantes galegos parecen ter moi claro os efectos positivos deste tipo de estratexias.

Na consideración dos resultados, hai que diferenciar tamén entre poder obxectivo, medible socialmente, e o poder que o falante dá ao oínte. Isto é observable nos casos nos que non había distancia social vertical entre falante e oínte (C); xa que, cando o falante lle pide algo ao oínte, cédelle poder para non ser impositivo. No caso dos falantes rurais (sobre todo os máis vellos) que empregan con frecuencia suxestións mitigadas, isto parece máis marcado: mostran ostensivamente a necesidade ou o desexo pero sométense á vontade do oínte que acaba por ter a responsabilidade do intercambio. Aínda que esta fórmula é tamén usada por falantes urbanos, estes poñen en funcionamento un abano de estratexias máis amplo. Ao aumentar o risco para a imaxe pública, os falantes de orixe urbana reforzan a súa argumentación: fan peticións máis longas e con maior número de reforzos (mitigadores ou intensificadores dependendo da situación). Mentres na mesma situación, os falantes rurais centran a súa estratexia no reforzo da cortesía codificada, na ostensión da necesidade e na cesión de poder ao falante.

O parámetro da distancia horizontal é o que máis afecta á presenza de (des)cortesía codificada e (des)cortesía interpretada. Canta máis familiaridade menos necesaria e máis estraña se fai a cortesía codificada. Como sinala Briz (2004), nestes casos a cortesía codificada podería ser mesmo interpretada como descortesía. Emprégase sobre todo cortesía de solidariedade (codificada ou non) porque como sinalan moitos falantes cando teñen que pedir a un amigo que lles pague un café, isto non supón un gran esforzo:

76. UM4: [aos meus amigos? /// bueno [risas] me parece algo como mui contián] (X)esquecín// as pelas(X) / invítame /// son os amigos bueno unhas veces o fan eles e outras o fago eu $(\mathrm{C} 1 \mathrm{~F}+)$

77. UH4: Ai [risas] non hai con que pagar $\uparrow$ [risas] espero que me convides $\uparrow$ [cantando] pero estou sen un caaan $\uparrow[$ cantando][risas] home! Si son colegas $\rightarrow(\mathrm{C} 1 \mathrm{~F}+)$

Se o poder e a familiaridade afectan sobre todo á realización do núcleo da petición e o uso de reforzos de cortesía ou de minimización da imposición, a relevancia condiciona especialmente as xustificacións e as promesas de compensación. Canto maior é a relevancia, máis sente o falante a obriga de demostrar a necesidade que ten de levar a cabo a petición e de asegurar algún tipo de compensación ao oínte, deste realizar o requirido. 
A variedade na escolla de estratexias comunicativas segundo a procedencia, a idade e o sexo dos informantes tamén se revelou interesante. Coa diferenciación de falantes urbanos e falantes rurais pretendíase abarcar toda unha serie de características que se conxugan nesta oposición. Os falantes urbanos, mesmo se o galego é a súa primeira lingua e vehículo habitual de comunicación, teñen un contacto moito maior co castelán que os falantes rurais.

Outro aspecto a ter en conta é o nivel de formación. A práctica totalidade dos falantes urbanos ten estudos superiores (para todos os grupos de sexo e idade), mentres que só dous dos falantes rurais maiores teñen estudos superiores e dous dos novos estudos medios; no resto o nivel de estudos é o básico. Como sinala Hernández Sacristán (1995: 318), a relación de estrutura social e estrutura lingüística é altamente relevante para a sociopragmática, polo que non se pode esquecer a gran diferenza que existe entre as estruturas dunha comunidade rural e dunha comunidade urbana. Mesmo se hoxe en día estas diferenzas parecen ir atenuándose, os resultados que obtemos demostran que na lingua isto aínda está bastante presente.

Alén de todas as diferenzas presentadas en relación ao poder e á familiaridade, en xeral, as estratexias preferidas por falantes urbanos e rurais son distintas. Probablemente o que máis chama a atención é a "lonxitude" das peticións. Os falantes urbanos argumentan a súa petición: canto máis difícil é o pedido, máis traballada está a argumentación cara ao fin que tentan acadar. Isto non é así en falantes rurais que sempre empregan intervencións moito máis breves, aínda que non máis directas. Pódense manexar varias hipóteses para explicar isto. En primeiro lugar, cabe a posibilidade de que estes últimos se sentisen máis cohibidos ante a enquisa e contestasen de forma menos descontraída, mais o grao de familiaridade da enquisadora con case todos eles é maior que cos falantes urbanos que colaboraron. Alén disto, as poucas peticións recollidas de forma espontánea tampouco desmenten este dato.

Podería ter maior consistencia relacionalo co nivel de formación. Autores como Bourdieu sinalan a relevancia deste parámetro no abano de recursos que un falante ten para a expresión lingüística. Probablemente é un aspecto a ter en conta, aínda que se analizamos as intervencións de falantes rurais con formación superior (RMM1 e RMH1) non parece que esta hipótese sexa tan relevante, xa que as súas estratexias son similares ás do conxunto.

Aínda que estes dous factores poidan influír nas diferenzas destes grupos, parece haber un compoñente cultural nada desprezable. Os falantes rurais en situacións que supoñen un risco para a imaxe pública, non empregan tantos reforzos como os falantes urbanos nin grandes argumentacións para soster a súa petición. Recorren a núcleos nos que a forza ilocutiva está máis mitigada: prefiren a suxestión, centrarse nas condicións preparatorias ou realizar peticións indirectas. Como reforzo, empregan sobre todo marcas de cortesía e xustificacións breves, concisas. Ademais, en moitas situacións preferiren non facer a petición, sobre todo se a relevancia é 
alta e a distancia social horizontal é grande. Pola contra, cando existe familiaridade, as súas peticións son moito máis directas e abertas que as empregadas por falantes urbanos.

Nos falantes de procedencia rural, parece confirmarse a polarización das estratexias de petición respecto do parámetro de familiaridade, alén de gardaren maior respecto polas normas sociais que rexen os intercambios e preferiren o uso de fórmulas de cortesía convencionalizadas.

Hernández Sacristán (1995), baseándose nos traballos de Wierzbicka (1991), establece catro parellas de principios da interacción social que organizan valores culturais e actos de fala. Son o principio de non interferencia fronte ao principio de solidariedade e cordialidade $^{11}$, o principio de cerimonialidade fronte ao de autenticidade, o de mostra pudorosa do "ego" fronte ao principio de afectividade e o principio de relación fiduciaria (o home débese á norma) fronte ao principio de exculpación (a norma débese ao home). Os falantes máis tradicionais inclínanse, en maior medida que os falantes urbanos, polos primeiros termos da oposición.

Podemos explicar a preferencia por estratexias menos impositivas en virtude do principio de non interferencia. Canto ao segundo par, como sinala o mesmo autor, "no tránsito de sociedades máis tradicionais máis rixidamente xerarquizadas a sociedades modernas democráticas o principio de autenticidade foi gañando terreo ao principio de cerimonialidade" (Hernández Sacristán 1995: 325), o que explica a preferencia de falantes rurais polas marcas de cortesía e tamén por expresións máis ou menos convencionalizadas en determinadas situacións. Isto último tamén está relacionado co último dos principios, xa que se reduce a creatividade do falante en favor do uso de fórmulas "normais" na situación presentada. Igualmente na formulación máis extensa de falantes urbanos atopamos maior forza expresiva e os recursos de intensificación do discurso son máis frecuentes que nos de falantes rurais, o que demostra maior observancia do principio de mostra pudorosa do "ego".

Todo isto podería provocar que as peticións de falantes rurais fosen interpretadas como rudas e pouco auténticas por falantes urbanos, ao igual que as destes poderían despertar certo receo e desconfianza naqueles por exceso de interese.

O parámetro do xénero requiriría unha análise moito máis detallada da desenvolvida neste traballo. As imaxes sociais de homes e mulleres non se constrúen da mesma maneira; polo que, tanto as estratexias de cortesía que empregan como falantes, como a cortesía esixida en función do xénero do interlocutor son moi diferentes. Neste corpus, en xeral, as peticións realizadas por mulleres son menos impositivas que as feitas por homes. Dos vintecatro usos de mitigadores da imposición, só nove son utilizados por homes. Alén disto, a mitigación do discurso (especialmente

11 Como xa se viu, esta oposición é especialmente produtiva nos estudos de cortesía e en concreto nas estratexias preferidas por cada lingua para a formulación de peticións. 
empregando recursos suprasegmentais e de modificación) é maior nas intervencións femininas. Tamén, e para todos os grupos, se confirma un maior uso de cortesía convencionalizada na fala das mulleres, sobre todo cando aumenta a distancia social tanto vertical como horizontal.

Os datos referentes á idade confirman as conclusións de Briz (2004) sobre a valoración da (des)cortesía interpretada sobre a codificada e a importancia do reforzo dos lazos de solidariedade nos falantes máis novos. Os falantes rurais deste grupo de idade seguen a presentar a maioría dos trazos vistos para os falantes deste ámbito.

\section{Conclusión}

Os primeiros estudos comparativos sobre cortesía intentaban dilucidar cales das cinco estratexias de cortesía propostas por Brown/ Levinson, presentadas anteriormente eran preferidas polos falantes. Nunha escala como a proposta por Blum-Kulka (2000) que teña nos seus extremos cortesía de solidariedade e cortesía de deferencia respectivamente, o galego, aínda estando dentro de culturas que prefiren a cortesía de solidariedade, tería unha posición máis central que outras linguas románicas como o castelán. Pero isto parece levar a unha análise pouco uniforme e simplificadora.

Tratando de ir máis alá, xustificar a preferencia de estratexias indirectas e pouco impositivas unicamente por deferencia, non se axusta á complexidade do ritual de coidado da imaxe. Insístese na importancia da cortesía negativa nas peticións en todas as linguas, xa que o acto en si supón un ataque á imaxe negativa do oínte. Porén no galego o falante sente a petición como un forte perigo para a súa propia imaxe positiva e inviste moito esforzo en mitigalo: busca "desresponsabilizarse" da petición, prefire recorrer á necesidade e á obrigatoriedade fronte ao desexo ou á orde, ademais de xustificarse e demostrar a incomodidade por ter que apelar ao oínte. O máis censurable en galego parece ser comprometer a imaxe do outro (tanto a positiva como a negativa).

Mais o falante, coñecedor das regras, emprega isto como parte importante da súa estratexia: dentro do xogo da petición o oínte tamén deberá coidar a imaxe do seu interlocutor. Así, o falante prefire transferirlle o poder e a responsabilidade do intercambio, para o que emprega a suxestión e a ostensión do desexo ou a necesidade. Para o reforzo do sentimento de filiación ou da imaxe positiva parece que en galego é fundamental estar disposto a coidar e non comprometer en ningún momento a imaxe do outro, a gardala e reforzala sobre a imaxe dun mesmo. Unha lectura similar da retranca fai Piccardi (2004), aínda que non chega a relacionala coas estratexias de cortesía.

Fronte ao que acontece en español, segundo mantén Diana Bravo (1999), onde ser consciente das calidades propias e traspoñer a confianza interpersonal de ámbitos 
familiares ao resto de relacións é considerado como positivo, en galego o máis importante parece coidar a imaxe do oínte, moitas veces a costa da do falante, sobre todo en situacións de distancia social, nas que rexen normas moi diferentes ás propias de situacións de familiaridade.

Respecto de interferencias máis concretas do español sobre o galego en estratexias de cortesía, parece que o condicional non é un tempo empregado tradicionalmente para este fin. Fronte a este tempo os falantes máis tradicionais prefiren o presente, o imperfecto e probablemente o futuro. Os falantes de procedencia rural non usan en ningún caso o condicional e entre os falantes urbanos é máis frecuente entre os novos e en situacións cotiás nas que falante e oínte non teñen ningunha relación, isto é, situacións nas que se prefiren as fórmulas máis convencionalizadas polo uso.

Parece que o núcleo interrogativo empregando o condicional de cortesía e baseado en condicións previas (“podería pasar diante?": UM1) máis convencionalizado en castelán está a competir co emprego doutras formas con núcleo condicional ("se fai favor e me deixa pasar, eu acabo axiña": RMH2) ou de modo imperativo ("por favor, déixeme pasar, que é pouca cousa": RMM2).

Debemos considerar os resultados deste traballo como provisionais, xa que, alén de constituír isto unha primeira achega, é necesario un estudo cuantitativo para poder avaliar o alcance das conclusións. Porén, cremos que si se comprobou a existencia de diferenzas pragmáticas entre galego e castelán e as interferencias neste nivel. Queremos subliñar a necesidade de que os estudos sobre lingüística non descoiden estes aspectos, para poder fornecer de ferramentas imprescindibles ámbitos máis prácticos como a didáctica da lingua ou a tradución.

\section{Bibliografía}

Álvarez Muro, A. (2005): Cortesía y descortesía: teoría y praxis de un sistema de significación. Estudios de Lingüística del Español, 25 [en liña]. Dispoñible en: $<$ http://elies.rediris.es/elies25/> [consult.: 08.05.2008].

Beebe, L. M./ Cummings M. C. (1996): "Natural speech act data versus written questionnaire data: How data collection method affects speech act performance", en Gass, S. M. / Neu, J. (ed.) (1996), Speech Acts Across Cultures. Studies on Language Acquisition, 11: 65-83.

Blum-Kulka, S. (1987): “Indirectness and politesness in requests: same or different?", Journal of Pragmatics, 11: 131-146.

Blum-Kulka, S. (1996a): "Introducción a la pragmática del interlenguaje”, en Cenoz, J. / Valencia, J. F. (ed.), La competencia pragmática: elementos lingüísticos y psicosociales: 155-175 (Bilbao: Universidad del País Vasco / EHU, 1996). 
Blum-Kulka, S. (1996b): "Variaciones en la formulación de peticiones", en Cenoz, J. / Valencia, J. F. (ed.), La competencia pragmática: elementos lingüísticos y psicosociales: 179-194 (Bilbao: Universidad del País Vasco / EHU, 1996).

Blum-Kulka (2000): "Pragmática del discurso", en Van Dijk (ed.), El discurso como interacción social: 67-100 (Barcelona: Gedisa).

Blum-Kulka, S. / House, J. / Kasper, G.. (eds.) (1989), Cross-cultural pragmatics: request and apologies (Norwood: Ablex).

Bravo, D. (1999): “¿Imagen “positiva” vs. imagen “negativa”? Pragmática socio-cultural y componentes de face", Oralia, 2: 154-184.

Bravo, D. (2004): "Tensión entre universalidad y relatividad en las teorías de cortesía", en Bravo, D. Briz, A. (eds.), Pragmática sociocultural: Estudios sobre el discurso de cortesía en español: 15-38 (Barcelona: Ariel).

Bravo, D. / Briz, A. (eds.), Pragmática sociocultural: Estudios sobre el discurso de cortesía en español (Barcelona: Ariel).

Bravo, D. (ed.) (2005): Estudios de la (des)cortesía en español: categorías conceptuales $y$ aplicaciones a corpora orales y escritos (Buenos Aires: Dunken).

Briz, A. (2001): El español coloquial en la conversación: esbozo de pragmagramática (Barcelona: Ariel).

Briz, A. (2004): “Cortesía verbal codificada y cortesía verbal interpretada en la conversación”, en Bravo, D. / Briz A. (eds.): Pragmática sociocultural: Estudios sobre el discurso de cortesía en español: 67-94 (Barcelona: Ariel).

Briz, A. (2007): “Atenuación y cortesía verbal en la conversación coloquial: su tratamiento en la clase de ELE", en Actas del programa de formación para profesorado de ELE: 2006-2007: 9-49 (Múnich: Instituto Cervantes).

Briz, A. / Grupo Val.Es.Co (2002): Corpus de conversaciones coloquiales (Madrid: Arco Libros).

Brown, P. / Levinson, S. (1987): Politeness. Some universals in language usage (Cambridge: Cambridge University Press).

Casanova, M. I. (1992): Actos ilocutórios directivos: a força do poder ou o poder da persuasão Tese doutoral (Lisboa: Universidade de Lisboa).

Cenoz, J. / Valencia, J. F. (1996): "Las peticiones: una comparación entre hablantes europeos y americanos", en Cenoz, J. / Valencia, J. F. (ed.), La competencia pragmática: elementos lingüísticos y psicosociales: 225-238 (Bilbao: Servicio editorial. Universidad del País Vasco / EHU).

Cirelli Apa, R. (2005): Polidez lingüística nas conversações de Telemarketing (São Paulo: Universidade de São Paulo) [en liña]. Dispoñible en: $<\mathrm{http}: / /$ www.teses. usp.br/teses/disponiveis/8/8142/tde-01082006-142049> [consult.: 08.05.2008].

Cohen, A. (1996): "Investigating the production of speech act sets", en Gass, S. M. / J. Neu (ed.) (1996), Speech Acts Across Cultures. Studies on Language Acquisition, 11: 21-43. 
Dobao, X. A. L. (1999): “Un máster de galego na aldea. Discursos (e silencios) públicos ó redor do galego oral", en Álvarez, R. / Vilavedra, D. (eds.), Cinguidos por unha arela común. Homenaxe ó profesor Xesús Alonso Montero. Tomo I. Semblanza e creación. Lingua. Historia, cultura e sociedade: 349-366 (Santiago de Compostela: Universidade de Santiago de Compostela / Departamento de Filoloxía Galega).

Dobao, X. A. L (2004): “O discurso oral público galego”, en Álvarez, R. / Fernández Rei, F / Santamarina, A. (eds.), A lingua galega: historia e actualidade, Vol. II: 297-306 (Santiago de Compostela: Instituto da Lingua Galega / Consello da Cultura Galega).

Escandell Vidal, M. V. (1998): “Cortesía y relevancia”, La pragmática lingüistica del español. Diálogos hispánicos, 22: 7-24.

Escandell Vidal, M. V. (2004): La comunicación (Madrid: Gredos).

Fernandes Rodrigues, D. (2002): Cortesía lingüistica: uma competência discursivotextual. Tese de Doutoramento (Lisboa: Universidade Nova de Lisboa).

Fonseca, J. (1994): Pragmática Lingüistica. Introdução, Teoria e Descrição do Português (Porto: Porto Editora).

Freixeiro Mato, X. R. (2003): Gramática da lingua galega. IV. Gramática do texto (Vigo : A Nosa Terra).

Gass, S. M. / Neu, J. (ed.) (1996): Speech Acts Across Cultures. Studies on Language Acquisition, 11 (Berlin-New York: Mouton de Gruyter).

Goffman, E. (1967): Interaction ritual. Essays on face-to face behavior (New York: Anchor Books).

Gómez Capuz, J. (1998): "Pragmática intercultural y modelos extranjeros: la interferencia pragmática en los doblajes al español de películas y seriales norteamericanos", en Sánchez, A. / Salvador, V. / Gómez, J. R. (eds.), Quaderns de Filologia. IV: Estudis Lingüistics. Pragmàtica intercultural: 135-151 (Valencia: Universitat).

Grice, P. (1991): “Lógica y conversación”, en Valdés Villanueva, L. M. (ed.), La búsqueda del significado (Madrid: Tecnos).

Haverkate, H. (1994): La cortesía verbal. Estudio pragmalingüistico (Madrid: Editorial Gredos).

Hernández Sacristán, C. (1995): “Actos de habla desde una perspectiva contrastiva: apuntes metodológicos", en Pragmática y gramática del español hablado: Actas del II simposic sobre Análisis del Discurso Oral: 317-328 (Zaragoza: Libros Pórtico) [en liña]. Dispoñible en: <http://dialnet.unirioja.es/servlet/ monografia?clave_monografia $=701>$ [consult.: 08.05.2008].

ILTEC [Instituto de Linguística Teórica e Computacional] (2005): “Análise de actos ilocutórios directivos: o pedido e a ordem", en Diversidade Linguística na escola portuguesa [en liña]. Dispoñible en: www.iltec.pt/divling/_pdfs/cd2_actosilocutorios_analise.pdf [consult.: 08.05.2008]. 
Kabatek, J. (1991): "Interferencias entre galego e castelán: problemas do galego estándar”, Cadernos da Lingua, 4 : 39-48.

Kabatek, J. (2004): “A diferenciación diafásica do galego actual”, en Álvarez, R. I Fernández Rei, F. / Santamarina, A. (eds.), A lingua galega: historia e actualidade. Vol. II: 379-388 (Santiago de Compostela: Instituto da Lingua Galega / Consello da Cultura Galega).

Kerbrat-Orecchioni, C. (1992): Les interacitions verbales. Vol. II (Paris: Armand Colin).

Lakoff, R. (1973): “The Logic and Politeness; or, Minding Your P's and Q's”, en Papers from the Ninth Regional Meeting of the Chicago Liguistic Society: 292-305.

Leech, G. (1997): Principios de pragmática (Logroño: Universidad de la Rioja).

Lenertz Marcotulio L. / Lima da Souza, S. (2007): "A teoria da polidez de Brown e Levinson aplicada ao português brasileiro: desafios e propostas", en IX Semana Nacional de Estudos Filológicos e Lingüísticos [en liña]. Dispoñible en: < http:// www.filologia.org.br/ixsenefil/anais/07.htm> [consult.: 08.09.2008].

Lorenzo Suárez, A. M. (2004): “Algunhas consideracións teóricas sobre as consecuencias funcionais e estructurais do contacto na lingua galega, en Álvarez, R. / Fernández Rei, F. / Santamarina, A (eds.), A lingua galega: historia e actualidade. Vol. II: 309-324 (Santiago de Compostela: Instituto da Lingua Galega / Consello da Cultura Galega).

Márquez Reiter, R/ Placencia, M. E. (2005): Spanish Pragmatics (Gran Bretaña: Palgrave).

Moledo Leirado, M. [Moreda Leirado, M.] (2007): "Marcadores conversacionais como marca de cortesía no Galego actual", en Chrystello, C. / Chrystello, H. (org.): Galiza: Berço da Lusofonia. Actas do V Colóquio Anual da Lusofonia: 185198 (Bragança: Arcosonline) [en liña]. Dispoñible en: www.arcosdigital.com/ ebooks/galiza-berco-da-lusofonia.pdf [consult.: 08.05.2008].

Moreno Cabrera, J. C. (1994): “Actos de Habla: definición y tipología. Actos de habla indirectos. La lógica de los actos de habla”, en Curso universitario de Lingüistica General. Vol. II: Semántica, pragmática morfología y fonología (Madrid: Síntesis).

Mulder, G. (1998): “Un estudio empírico de los actos de habla directivos en español”, La pragmática lingüistica del español. Diálogos hispánicos, 22: 237-276.

Peres de Oliveira, T. (2005): "Condicionais, atenuação e polidez: um estudo das estrategias comunicativas das condicionais", Alfa, 49, 1: 123-137 [en liña]. Dispoñible en: www.alfa.ibilce.unesp.br/download/v49/v49-1/cap7.pdf [consult.: 08.05.2008].

Piccardi, A. (2004): “A retranca como acto lingüístico", Cadernos da lingua, 26: 99108.

Placencia, M. E. / Bravo, D. (eds.) (2002): Actos de habla y cortesía en español. Lincon Studies in Pragmatics, 05 (Muenchen: Lincom Europa). 
Placencia, M. E./ García, C. (eds.) (2007): Research on Politeness in the Spanishspeaking world (Mahwah: Lawrence Erlbaum Associates).

Rosales Sequeiros, X. (2005): "Current Issues in Galician Semantics and Pragmatics", Lincom Studies in Romance Linguistics, 45.

Sperber, D. / Wilson, D. (1994): La relevancia (Madrid: Visor).

Watts, R.J. (2003): Politeness (Cambridge: Cambridge University Press).

Wierzbicka, A. (1991): Cross-cultural pragmatics: The semantics of human interaction (New York: Mouton de Gruyter). 


\section{Anexo I: Símbolos usados na transcrición}

- $\quad$ Reinicios e autointerrupcións sen pausa

/ Pausa corta, inferior a medio segundo

// Pausa entre medio segundo e un segundo

/// Pausa dun segundo ou máis

(3") Silencio (lapso ou intervalo) de 3 segundos;indícase o número de segundos nas pausas de máis dun segundo

$\downarrow \quad$ Entoación descendente

$\uparrow \quad$ Entoación ascendente

$\rightarrow \quad$ Entoación mantida ou suspendida

NEno Pronuncia marcada e enfática (dúas ou máis letras maiúsculas)

ne no Pronuncia soletreada

${ }^{\circ}()^{\circ} \quad$ Fragmento pronunciado cunha intensidade baixa

ee Alargamento vocálico

nn Alargamento consonántico

? Entoación interrogativa

! Entoación exclamativa

(()) Transcrición dubidosa

[risas] Outros datos sobre a entoación, paralinguaxe... que nos pareceron interesantes foron anotados en caixas.

\& Solapamento das intervencións 